\title{
DOES SCHOOL QUALITY MATTER? \\ RETURNS TO EDUCATION AND THE \\ CHARACTERISTICS OF SCHOOLS IN SOUTH AFRICA
}

\author{
Anne Case \\ Motohiro Yogo \\ Working Paper 7399 \\ http://www.nber.org/papers/w7399 \\ NATIONAL BUREAU OF ECONOMIC RESEARCH \\ 1050 Massachusetts Avenue \\ Cambridge, MA 02138 \\ October 1999
}

We thank Angus Deaton and seminar participants at Princeton University for comments. We gratefully acknowledge financial support from the John D. and Catherine T. MacArthur Foundation. The views expressed herein are those of the authors and not necessarily those of the National Bureau of Economic Research.

(C) 1999 by Anne Case and Motohiro Yogo. All rights reserved. Short sections of text, not to exceed two paragraphs, may be quoted without explicit permission provided that full credit, including $\odot$ notice, is given to the source. 
Does School Quality Matter? Returns to Education and the

Characteristics of Schools in South Africa

Anne Case and Motohiro Yogo

NBER Working Paper No. 7399

October 1999

JEL No. I2, O1

\section{$\underline{\text { ABSTRACT }}$}

This paper contributes to what is known about the impact of school quality, by documenting its effect on the incomes of Black South Africans, using data from the 1996 South African census and two national surveys of school quality. South Africa provides an interesting laboratory for studying the impact of school quality on labor market outcomes. Under the Apartheid system, Blacks faced extremely limited residential and school choices, which limits the extent to which results are attributable to the endogeneity of school and residential choice. In addition, Black schools' funding and staffing decisions were made rather arbitrarily by a White government that was at best indifferent to the needs of Black schools. Large differences in pupil/teacher ratios developed between Black schools, differences much larger than those observed in the United States. Using a two-state estimation procedure similar to that employed by Card and Krueger (1992) and by Heckman et al. (1996), we find that the quality of schools in a respondent's magisterial district of origin has a large and significant effect on the rate of return to schooling for Black men. The South African results are notable, moreover, because they are so similar to those estimated by Card and Krueger (1992) for the United States.

Anne Case

Department of Economics

Princeton University

Princeton, NJ 08544

and NBER

accase@princeton.edu
Motohiro Yogo

Department of Economics

Princeton University

Princeton, NJ 08544

myogo@princeton.edu 


\section{Introduction}

The effect of school inputs on labor market outcomes is an important and controversial topic, both in the United States and in developing countries. A large literature about American schools has not settled debate on the issue. Card and Krueger (1992) estimate the effect of pupil/teacher ratios and teachers' salaries on the rate of return to education for men born between 1920 and 1950, observed in the 1980 census. Controlling for state of birth effects, state of residence effects, and differences in returns to education between regional labor markets, they find a large, negative and significant effect of pupil/teacher ratios on the rate of return to education. Hanushek et al. (1996) and Heckman et al. (1996) challenge aspects of the Card and Krueger analysis. Hanushek et al. notes that the level at which school characteristics are aggregated affects the estimation results, and claims that aggregation biases upward estimated school quality effects. Heckman et al., replicating the Card and Krueger results in the 1970, 1980, and 1990 censuses, makes clear the importance of allowing for non-linearities in the returns to education when estimating the impact of school resources, and of allowing for differences in the impact of school quality across labor markets. They find school quality effects are weak for those with exactly 12 years of schooling, and strong only for those who attend college. Card and Krueger (1996) present a thorough review and discussion of this literature, but debate on how to interpret the literature on American schools is far from settled.

This paper contributes to what is known about the impact of school quality, by documenting its effect on the incomes of Black South Africans, using data from the 1996 South African census and two national surveys of school quality. Debate on school resources in South Africa has sharpened in the aftermath of Apartheid. The school teachers' union was a strong 
supporter of the African National Congress (ANC), and worked diligently for its election. The teachers' union has become a powerful voice in post-Apartheid South Africa. With a fixed budget for schools, teachers have pushed for higher salaries for Black teachers (to reach parity with the salaries of White teachers), at the expense of pupil/teacher ratios and other school resources. Officials in Pretoria have referred to Hanushek (1996) in justifying their decisions to increase salaries, rather than reduce pupil/teacher ratios. In this paper, we estimate three channels through which deprivation in school resources affects the outcomes of an entire generation of Black South Africans: educational attainment, probability of employment, and returns to education.

For several reasons, South Africa provides an interesting laboratory for studying the impact of school quality on labor market outcomes. Under the Apartheid system, Blacks faced extremely limited residential and school choices, which limits the extent to which results are attributable to the endogeneity of school and residential choice. In addition, Black schools' funding and staffing decisions were made rather arbitrarily by a White government that was at best indifferent to the needs of Black schools. Large differences in pupil/teacher ratios developed between Black schools, differences much larger than those observed in the United States. The mean pupil/teacher ratio by magisterial district (county-sized regions) in Black South African schools in 1991 varied from 23 to 67 , compared with the variation in pupil/teacher ratios by state from 17 to 35 (Card and Krueger, 1992, Table 1). The large differences in pupil/teacher ratios between magisterial districts in South Africa allow us a look at the impact of school quality over a range not observed in the United States. The South African data are reported at the magisterial district level, of which there are 360 in the country. Magisterial districts are comparable to U.S. counties, which also limits any role for aggregation bias in the analysis. The South African results 
are notable, moreover, because they are so similar to those estimated by Card and Krueger (1992) for the United States.

Using a two-stage estimation procedure similar to that employed by Card and Krueger and by Heckman et al., we find that the quality of schools in a respondent's magisterial district of origin has a large and significant effect on the rate of return to schooling for Black men. A decrease in the pupil/teacher ratio of 5 students would, on average, be associated with an increase in the return to education of roughly 1 percent. Our estimates of the impact of school quality are, in general, about twice as large as those estimated by Card and Krueger (1992) for the United States. These results are robust to the two critical points raised by Heckman et al. That is, they are robust to allowing the return-to-education-by-district-of-origin coefficients to vary between provincial labor markets, as well as to allowing log income to be non-linear in years of completed schooling.

We also find that school quality significantly affects educational attainment and the probability of employment. Our modal point estimate of the effect of the pupil/teacher ratio on years of completed schooling is identical to that estimated by Card and Krueger for cohorts of men born in the United States between 1920 and 1950: reducing the pupil/teacher ratio by 10 students would, all else equal, increase completed schooling by 0.6 years. This finding is also consistent with the earlier results of Case and Deaton (1999). Focussing specifically on the impact of school inputs on educational attainment in South Africa, using a 1993 nationally representative survey, Case and Deaton estimate that a student who has attended a school where the pupil/teacher ratio is 10 students lower will have completed 0.6 years of additional schooling by age 18 . 
We begin in Section II by introducing the South African data. Section III presents estimates of the effect of school quality on rates of return to education and results from a number of specification checks. Section IV broadens the analysis to include the impact of school quality on years of completed education and the probability of employment, and Section $\mathrm{V}$ concludes.

\section{School Quality in South Africa}

Under Apartheid, no fewer than 11 different school administrations were responsible for schools attended by Black students. The Department of Education and Training (DET) was responsible for Black schools in the four provinces that the White government envisioned as comprising the "new" South Africa—Cape, Free State, Natal and Transvaal—while schools in the "self governing territories" and "independent homelands" were financed (separately) by the White government in Pretoria. ${ }^{1}$ (See Case and Deaton (1999) for details on school funding.)

School quality can be documented using two school surveys, one conducted in 1991 and the other in 1996. The Education Atlas of South Africa recorded the number of pupils and teachers in each of the country's 360 magisterial districts by race in 1991. With few exceptions, students would have attended schools only with members of their own racial group. ${ }^{2}$ Marked variation in the quality of Black schools developed between magisterial districts during Apartheid. This can be seen in Map I, which presents the magisterial district average pupil-teacher ratios for

\footnotetext{
${ }^{1}$ Technically, schools in the "independent homelands" were funded out of "foreign aid" from the government in Pretoria.

${ }^{2}$ Under Apartheid, South African racial groups were marked as African (or Black), Coloured (mixed race), Asian (or Indian), and White. We will use capital letters to denote that we are referring to these Apartheid racial categories.
} 
Blacks students in 1991. In some districts, the average pupil/teacher ratios were as low as 12 and, in others, were upwards of 70 . The highest pupil-teacher ratios were concentrated in areas that had been designated "independent homelands" — now parts of the Eastern Cape (the southeastern end of the country) — and in Mpumalanga and KwaZulu-Natal (along the easternmost edge).

The change of government in 1994 did not bring immediate change in the conditions of schools. Map II presents pupil-weighted median learner/educator ratios by magisterial district for all primary schools in the country in 1996. This information is drawn from the School Register of Needs Survey, our second source of information on school quality, which was conducted in 1996. There is a large number of magisterial districts in which the median school's learner/educator ratio lies between 45 and 80 . These districts tend to be the same districts for which we observed high 1991 pupil/teacher ratios. (The correlation coefficient between the pupil/teacher ratio in Black schools in 1991 and the median learner/educator ratio in 1996 is 0.6.) Some areas of the country in which primary schools have the lowest pupil-teacher ratios are the least densely populated areas (as in the desert of the Karoo in the Southwest), and later disappear from our analysis altogether, because there are no African persons observed having been educated there.

The 1996 survey did not collect information on the race of students. However, the Black population is roughly 75 percent of the entire population and is a younger population than the White, Coloured and Asian populations, and comprised the vast majority of school-aged children in 1996. We will use the 1996 data in two different ways. First, the 1996 survey collected a richer set of quality measures, such as adequacy of textbooks, and we will use these below. In addition, in Section III we use our 1996 measure to control for measurement error in the reported 1991 pupil/teacher ratio. 
We will rely primarily on the 1991 school quality measure, both because it allows us to focus on Black schools, and because it represents school quality at a time when many of the young adults in the 1996 census would still have been in school. An estimate of the fraction of men and women aged 24 to 34 that would have been in school in 1991 is presented in Table I. These numbers have been calculated using the (100\% sample) 1991 South African census, which enumerated the entire country except for the "independent homelands" of Transkei, Ciskei, Bophutatswana and Venda (TBVC), which the government was treating as separate countries. We see from Table I that 60 percent of persons aged 24 in 1996 are estimated to have been in school in 1991 (Panel A for men, Panel B for women). Of those, 90 percent were still working toward a high school degree. Roughly 20 percent of persons aged 28 in 1996 are estimated to have been in school in 1991 and, of those, 70 percent had not completed high school.

As Table I makes clear, many respondents in our sample would have been in school in 1991. However, the majority were not. To the extent that the pupil/teacher ratio for 1991 does not capture the pupil/teacher ratio at the time when older respondents were in school, our estimated effect of school quality will be biased. We return to this, and present estimates of the size of this bias, at the end of Section III.

We estimate the impact of school quality on the returns to education using the 1996 South African census (10 percent public release sample). This census is a particularly good tool for this exercise because, in addition to income and education, individuals are asked where they currently live and whether they migrated from elsewhere. Information is collected on the magisterial district from which the respondent migrated, and on the magisterial district within which he or she is 
currently employed. ${ }^{3}$ Income information is released by income category, and we assign

individuals the conditional expectation of income within each income category, assuming a normal distribution for log income. (Details available from the authors upon request.) Income may include transfers as well as earnings, but in the 24 to 34 year old age group, government transfers are a rare source of income. ${ }^{4}$

We analyze only 24 to 34 year olds, so that the 1991 school quality measures might better reflect the quality of schools attended by those we study. Average years of education for Blacks aged 24 to 34 are given in Table I by gender and employment status, together with an estimated rate of return to education for that age and sex from an OLS regression of log earnings on years of completed schooling and a constant. In addition, Table I presents information on the fraction of each age group that is employed, and the fraction that has migrated to this magisterial district from another.

Working men between the ages of 24 and 34 have completed roughly 8.4 years of schooling, with the mean years increasing slightly to age 27 and declining beyond that point. This is consistent with earlier findings; many Black adults continue to be enrolled in school into their mid-twenties (Case and Deaton (1999)), and each subsequent age cohort is observed completing

\footnotetext{
${ }^{3}$ The census asks "In which year did this person move to the dwelling where he/she usually lives?" and if the response is anything except "The person has never moved," then a follow-up question is asked: "From where did this person move?" and the name of the magisterial district is recorded. We have no choice but to assume that the place of origin is the place where the person was educated.

${ }^{4}$ The 1995 October Household Survey of South Africa asked questions on grants and on employment. Of the 15368 Black men and women between the ages of 24 and 34 who were interviewed in the OHS95, only 2 percent report receiving a pension, a disability or other grant, material assistance, skill training, or social work services. Of those who reported that they were working full- or part-time, only 1 percent reported receiving a government grant or transfer.
} 
more education than the cohorts that came before (Thomas (1996)). The same pattern holds for working women, with the peak reached at age 26 . However, at each age, employed women have on average completed a greater number of years of schooling.

The estimated returns to a year of schooling are roughly constant throughout this age range. Men average a return of 9.5 to 10 percent, while the return on a year of education for women is higher, roughly 14 percent. This difference, as well as the difference in completed education between employed men and women, may be due to the large, significant difference in the employment of men and women at each age. (The difference in the fraction employed between 24 year old men and women is 0.208 , with a standard error of 0.005 ; the differences are significant for each age.) In Section IV we turn to the impact of school quality on the probability of employment.

In what follows, we will generally report results for men and women separately by age cohort (24-26, 27-29, 30-32, 33-34). We see little difference in our estimates between these age cohorts, and we often present additional results for the entire sample by gender.

\section{Returns to Education in South Africa}

We estimate the returns to school quality using a two-stage procedure similar to that employed by Card and Krueger (1992) and Heckman et al. (1996). ${ }^{5}$ In the first stage, we analyze the $\log$ of annual income $\left(\ln I_{i j b c}\right.$ ) for person $i$ who reports working in magisterial district $j$, who has moved from magisterial district $b$, in age cohort $c$. We regress log income on indicators of

${ }^{5}$ This model has what Heckman et al. refer to as the "beauty" of being derivable from a "richly interpretable economic model of how quality affects earnings." [p. 599] 
the magisterial district of employment $\left(D_{i j}\right)$, on indicators of the magisterial district of origin $\left(B_{i b}\right)$, on interaction terms between education and indicators of province of employment $\left(e d_{i} \times P_{i j}\right)$, and on interaction terms between education and indicators of the magisterial district of origin $\left(e d_{i} \times B_{i b}\right)$. We run regressions separately by age cohort $(24-26,27-29,30-32,33-34)$ and gender, and control for marital status $X_{i j b c}$. The first stage is, then:

(1) $\ln I_{i j b c}=\delta_{b, c} B_{i b}+\mu_{j, c} D_{i, j}+\rho_{p, c}\left(e d_{i} \times P_{i j}\right)+\gamma_{b, c}\left(e d_{i} \times B_{i b}\right)+\beta_{c} X_{i j b c}+\epsilon_{i j b c}$ Of the 360 magisterial districts in South Africa, we have observations on Black men and women working in 335 districts, having come from 307 districts. ${ }^{6}$ For each age cohort, we estimate 958 coefficients for equation (1): 335 district of employment intercepts, 307 district of origin intercepts, 307 estimates of returns to education by district of origin, 8 estimates of returns to education by province of employment, and an estimate of the return to marriage.

Differences in incomes that arise because of differences in mean characteristics of the magisterial district of origin (educational attainment of adults, or access to good health care, or access to good jobs because of the proximity of the magisterial district to a central business district, say) will all be absorbed by the $\delta_{b c}$ coefficients. The extent to which differences in school quality affect the intercepts will also be captured in these district-specific terms. Differences in incomes that arise because of differences in the mean characteristics of the magisterial district of employment (the tightness of the local labor market, differences in the local price level, additive local demand and supply shocks) will be absorbed in the $\mu_{j c}$ coefficients. The extent to which a regional labor market (here proxied by province of employment) pays a higher return to education

${ }^{6}$ Observations are included in the first stage only if they come from magisterial districts for which we have school quality information for the second stage. The results are robust to running the first stage without this restriction. 
will be captured in the $\rho_{p, c}$ coefficients. Finally, magisterial district of origin specific returns to education are captured in $\gamma_{b, c}$. It is the contribution of school quality to these rates of return to completed education that we analyze in detail below.

In the second stage, we take the magisterial district specific returns to education $\left(\gamma_{b, c}\right)$ and regress these on measures of magisterial district school quality $\left(Q_{b}\right)$ and other characteristics of the magisterial district from which the individual migrated $\left(W_{b}\right)$ :

$$
\gamma_{b, c}=\alpha_{c}+\phi_{c} Q_{b}+\theta_{c} W_{b}+u_{b, c}
$$

All individuals are assigned the school quality measures of the district they report having migrated from, and those who have not migrated are assigned the quality measure for the district they are currently living in (and have always lived in).

Implicit in this model is the assumption that log earnings are linear in years of schooling within each magisterial district (equation 1), and that the reduction in the pupil/teacher ratio has the same effect on small class sizes as on large (equation 2). In addition, the model assumes that the return-to-education-by-district-of-origin is the same in all labor markets. We will examine and relax these assumptions below. Finally, we are assuming that school quality in a magisterial district in 1991 is an accurate measure of the quality of schools that respondents attended. We examine this assumption in detail at the end of this section.

The first stage regressions yield estimates of returns to education by magisterial district of origin by age cohort and gender. We present these estimates for all men aged 24 to 34 estimated as one cohort_-in Map III, which plots these returns $\left(\gamma_{b}\right)$ geographically. It is apparent that many of the districts with the highest pupil-teacher ratios also have the lowest returns to education. Many of the magisterial districts in the Eastern Cape and KwaZulu-Natal have 
estimated returns to education that are insignificantly different from zero.

Results of second stage estimation, by gender and age cohort, are reported in Tables II

and III. The tables report weighted least squares estimates, where the inverse sampling variance of the returns to education from the first stage are used as weights. Generalized least squares estimates allowing for a full set of covariance terms (as in Hanushek 1974) provides essentially identical results.

The results for men in Table II are broken into four panels. The top two present results using the pupil-teacher ratio in Black schools in 1991 (or its log) as our measure of school quality, for all men in an age cohort. The second two panels restrict the sample to migrants only. The results in Table II are robust to the measure of pupil-teacher ratio used, and to restricting the sample to only men who have moved. For each age cohort taken separately, and for all men aged 24 to 34 taken together, the effect of the pupil/teacher ratio on returns to education is negative and significant, and almost identical for each cohort in each specification. A decrease in the pupilteacher ratio by 10 students would, on average, be associated with an increase in the return to education of roughly 2 percent. A reduction of the pupil/teacher ratio of 10 would result in an increase in earnings of 8 percent for a person obtaining 4 years of schooling (standard 2). These estimates are about twice as large as large as those estimated by Card and Krueger (1992), for U.S. schools for cohorts born between 1920 and 1950.

The effect of school quality on the returns to education for women are reported in Table III. These results are quite different from those for men. The effect of school quality is estimated to be much smaller, and to become significant only at later ages. For women aged 24-26, and 27 29 , neither the pupil/teacher ratio nor the $\log ($ pupil/teacher ratio) is significant, for the group as a 
whole or for the group of women who have migrated. For women aged 30-32 and 33-34, we observe a small, negative and (in some specifications) marginally significant effect of pupil/teacher ratios on wages, of roughly half the size observed for men. Only half as many women are employed at any age (Table I) and below we shall see that school quality has a positive effect on the probability of employment that is roughly three times larger for women than for men. This may be responsible for the difference observed between men and women in the impact of school quality.

\section{Alternative measures of school quality}

It may be that pupil/teacher ratios are negatively and significantly correlated with earnings, but that the effect works not through the number of students per classroom, but through some other mechanism that is correlated with pupil/teacher ratios. We explore this by regressing the returns to education on different measures of school quality. In Tables IV and V, we regress magisterialdistrict-of-origin returns on the proportion of teachers in that magisterial district without a Standard 10 (high school) education, and on the proportion of schools in the magisterial district that report textbook supplies as "adequate." Our measure of teachers without a high school degree comes from the (100\%) 1991 South African census, again excluding TBVC. We use here the proportion of Blacks who reside in a magisterial district, who identify themselves as teachers, but report having less than a Standard 10 education. (The 1991 census did not collect information on magisterial district of employment, and so we rely here on magisterial district of residence.)

Our second measure comes from the 1996 School Register of Needs data set, and is a magisterial district pupil-weighted mean of schools reporting that their textbook supply is "adequate" (as 
opposed to "inadequate" or "non-existent"). As Tables IV and V make clear, conditional on the pupil/teacher ratio, neither measure is significantly related to returns to education by magisterial district. Furthermore, these additional quality measures do not reduce the impact of pupil/teacher ratios on the returns to education for men. It may be that the adequacy of textbooks can change more rapidly than pupil/teacher ratios, and the 1996 measure may not reflect quality at the time people in our sample were in school. The education of teachers in the magisterial district in 1991 provides a reflection of teacher quality at the time many respondents in the 1996 census were in school, but because the 1991 census did not cover TBVC, we lose roughly 40 of the magisterial districts (some with very high pupil/teacher ratios and lower-skilled teachers) that may have contributed important information. Also, certainly some teachers would not have been working in the magisterial district in which they lived, so that our measure—based on residence—will be noisy. $^{7}$

It may be that school quality, as measured by pupil/teacher ratios, is correlated with characteristics of the households within which people in our sample were raised, and that it is the households' characteristics and not the pupil/teacher ratios that are responsible for the returns observed here. This is not likely to be the case in South Africa before the end of Apartheid, because Blacks had very little say in school funding or the provision of school resources. However, we test this by adding information on the mean years of completed education of men and women in the magisterial district from which the respondent came who are old enough to have been the respondent's parents (ages 49-59 in 1996). (The 1996 census did not collect

${ }^{7}$ A rough calculation based on the 1996 census is informative. Of the half million Black South Africans above the age of 21 who report being employed in the 1996 census, only 62 percent report living and working in the same magisterial district. 
information on the schooling of respondents' parents.) We restrict the sample to adults of this age who report never having changed magisterial districts, in order to better capture the adults present when our respondents were growing up. ${ }^{8}$ These results are presented in the last column for each age cohort in Tables IV and V. Older adults' education does not have a significant effect on returns to education for men, and does not change the estimated relationship between pupil/teacher ratios and returns to education for men. For women, older adults' education appears to be a much more significant determinant of returns to education. For women in each age cohort, an increase in the mean education of older adults of one year is associated with an increase in the return to education of almost one percent. Older adult education has little effect on the pupil/teacher ratio coefficients for women, which remain small and insignificant.

We take the evidence in Tables IV and V to show that the pupil/teacher ratio is not proxying for the quality of teachers' educations, nor the adequacy of textbooks, nor the education of the respondents' parents (or, at least, people in the parents' generation). The effect of pupil/teacher ratios on the returns to education for men aged 24-34 is robust to the addition of all of these measures. We turn now to check the robustness of these results when we relax the assumption of a linear relationship between years of completed education and log earnings. We then present provincial estimates of return-to-education-by-district-of-origin, and then turn to the assumption that the returns to education are linear in the pupil/teacher ratio. Finally, we examine the measurement error issues, before turning to impact of school quality on school completion and the probability of employment in Section IV.

\footnotetext{
${ }^{8}$ Results are very similar when all adults aged 49-59 are used in place of "stayers only."
} 


\section{Completed education and log earnings}

The first-stage of the models estimated above assumes that the relationship between log earnings and years of completed education in South Africa is linear. However, as Figure I makes clear, the South African data do not support this assumption. Figure I presents estimates of the returns to education for Black men and women ages 24 to 34 by year of completed education, controlling for marital status. The returns look roughly linear from 2 years of schooling, through to 11 years. Eleven years of education is Standard 9 in South Africa, and is one year short of "matric"-a high school degree. From matric through college and graduate programs (12 to 18 years of schooling), the returns to education are again roughly linear, but with a higher rate of return than that observed for people with less than matric. From zero to 2 years of schooling (which is less than a Standard 1 completion in South Africa), there is no return to additional education. The same pattern is observed for women, in the right panel of Figure I. These results are consistent with findings of Mwabu and Schultz (1998), and Lam (1999). We test whether this "kink" in the return to education is responsible for our results by breaking our samples of men and women into two education groups: those with 2 to 11 years of schooling and those with 12 to 18 years. We eliminate the observations with less than 2 years of schooling from this part of the analysis. We rerun the model put forward above, by education group, and present the results in Table VI. Again, we find for men the same large negative effect of pupil/teacher ratio on estimated returns to education. For the group with less than matric, the results are significant, with a $t$-statistic of 4.5. However, for the group with matric or more, the result is no longer significant at standard confidence levels, although the point estimate (-.0019) is identical to what it was before. The increase in the standard error is perhaps due to the smaller number of observations in the first 
stage, which is only half as large for the better educated group. The results for women also do not change, in the sense that they were small and insignificant before and remain so.

The results in Tables VI show that the impact of pupil/teacher ratios on the returns to education for men is not being determined by the change in the rate of return to education above 11 years.

\section{Allowing regional variation in returns-to-education-by-district-of-origin}

As Heckman et al. argues, the returns-to-education-by-district-of-origin may not be invariant across labor markets. It is not feasible for us to add 2700 additional coefficients to estimate district-of-origin coefficients for each of the nine South African provinces in one regression. Instead, we run both stages of our model separately for each of South Africa's nine provinces. In order to keep the sample sizes for the nine provinces large enough to obtain meaningful estimates, we estimate rates-of-return for the entire cohort of men aged 24-34 as one group. (This is apt to make little difference to the estimated coefficients, given the similarity in the returns presented thus far for the smaller age cohorts.) The first stage appears

(3) $\ln I_{i j b p}=\delta_{b, p} B_{i b}+\mu_{j, p} D_{i, j}+\gamma_{b, p}\left(e d_{i} \times B_{i b}\right)+\beta_{p} X_{i j b p}+\epsilon_{i j b p}$ where the coefficients now all reflect the fact that they have been estimated separately by province ( $p$ ) of employment. Results from the second stage estimation for men are presented in Table VII. We find a negative and significant effect of pupil/teacher ratios on returns to education in all but three provinces. In the Western Cape (-.0020), Free State (-.0041), KwaZulu-Natal (-.0015), Northwest (-.0013), Gauteng (-.0008), and Mpumalanga (-.0020) we find significant estimates close to those presented in Table 2, for all provinces taken together $(-.0020)$. In the three 
provinces where we do not find significant effects, the number of districts-of-origin coefficients in the second stage are small (91 observations in the Eastern Cape, 31 in the Northern Cape, and 68 in Northern province). These small numbers are due in part to the much smaller fraction of Blacks in the population in the Cape provinces, and to the fact that Statistics South Africa underrepresented Northern Province in this first 1996 data release. Grouping provinces into their natural geographic regions, we estimate regional returns-to-education-by-district-of-origin coefficients, and present the results of the second stage of estimation in panel B of Table VII. In three of the four regions, we find a large, negative and significant effect of pupil/teacher ratios on estimated returns to education, on the order of $(-.0015)$.

Results in Table VII show the return-to-education-by-district-of-origin responding to school quality in a similar manner across provinces, and again reveal a strong, negative and significant effect of pupil/teacher ratios on those returns.

\section{Non-linearities in the impact of pupil/teacher ratios}

As shown in Maps I and II, the variation in pupil/teacher ratios between magisterial districts is extremely large in South Africa. It may be that a reduction in the pupil/teacher ratio has a more pronounced effect when class sizes are large than when class sizes are small. We explore this by allowing a quadratic relationship between pupil/teacher ratios and returns to education. These results are presented in Tables VIII. For men (Panel A), we find evidence that the effect of school quality is larger at larger class sizes. The pupil/teacher ratio and its square are each highly significant when entered individually. Although their collinearity drives down the $t$-statistics on both when they are entered together, they are jointly highly significant determinants of the returns 
to education. For men aged 24-26, and for those aged 30-32, we estimate that a reduction in the pupil/teacher ratio by one child would result in a .0015 percent increase in the return to years of schooling at a class size of 30 , and a .0025 percent increase at a class size of 60 , all else held equal. These results also suggest why our estimated effects may be larger than those found in the United States: the mean pupil/teacher ratio by magisterial district in Black schools in 1991 varied from 23 to 67, while Card and Krueger report variation in average pupil/teacher ratios by state in their analysis from 17 to 35 (Card and Krueger, 1992, Table 1).

\section{Measurement error in measures of school quality}

The measure of school quality taken at time $t$ may not adequately capture the school quality at the time some of our respondents were in school, for at least two reasons. First, there may be measurement error in reported school quality for time $t\left(\epsilon_{t}\right)$. In addition, even if the Education Atlas provided average pupil/teacher ratios in 1991 that were free of measurement error, not every person in our sample would have been in school in 1991, and those who left earlier may have faced pupil/teacher ratios that were different from those in place in 1991. Let true school quality for a person being educated in period $e$ be represented by $Q_{e}$, and suppose that every year there is random shock to school quality in the district. (From discussions with economists and educators in South Africa, it is clear that this provides a fair description of the evolution of school quality in Black schools under Apartheid.) Observed school quality at time $T$ can be related to true school quality at time $e$ by the formula

$$
Q_{T}=Q_{e}+\sum_{t=e+1}^{T} u_{t}+\epsilon_{T}
$$

Under the assumption that these shocks to school quality $\left(u_{t}\right)$ are identically and independently 
distributed, the probability limit of estimated school quality effect is

$$
\operatorname{plim} \hat{\phi}=\frac{\sigma_{e}^{2}}{\sigma_{e}^{2}+(T-e) \sigma_{u}^{2}+\sigma_{\epsilon}^{2}} \quad \phi=\frac{\sigma_{T}^{2}-\sigma_{\epsilon}^{2}-(T-e) \sigma_{u}^{2}}{\sigma_{T}^{2}} \phi .
$$

In the absence of measurement error in our period $T$ quality measure (i.e., if $\epsilon_{T}=0$ ), if school quality were constant over time, then ${\sigma^{2}}_{u}=0$ and plim $\hat{\phi}=\phi$. In addition, if $\epsilon_{T}=0$, then when $e=T$, plim $\hat{\phi}=\phi$.

The first source of bias, error in the measurement of school quality at time T (here, 1991), can be removed using our 1996 measure of school quality as an instrument for our 1991 measure. The first stage regression result is

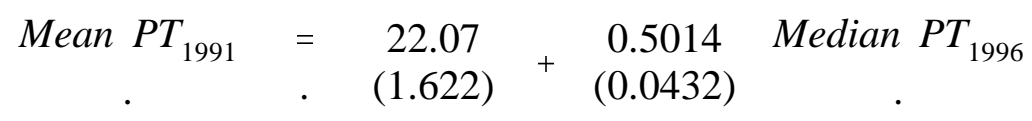

when the first stage regression is run on all 308 magisterial districts for which we have quality measures for both 1991 and 1996 (standard errors in parentheses).

Table IX presents the results of instrumenting school quality in 1991 with school quality in 1996 when estimating the effects of school quality on returns to education. There are several interesting findings here. For both men and women, the impact of school quality on returns to education becomes larger upon instrumentation. Results in Table IX show that instrumentation increases the impact of pupil/teacher ratios on returns to education by between 15 and 30 percent. The impact of pupil/teacher ratios also becomes larger and more significant for women aged 27 to 29, and for women aged 30 to 32 although, taken as a group, the results for women are far from robust.

Neither of our quality measures allows us to remove the attenuation bias caused by the 
shocks to school quality between the time a respondent was in school and the time the measurement of school quality was taken in 1991. However, we can estimate the extent to which our quality estimates are biased as a result of using a quality measure of the wrong vintage, under the assumption that quality evolves in the manner described above (independent, identically distributed shocks to quality each period). We obtain an estimate of the incremental attenuation bias as one moves from any age to the next higher age by first estimating a quality effect for every age from 24 to $60\left(\phi_{a}\right)$ —running our two-stage procedure for every age taken separately. Noting that age moves one-for-one with $(T-e)$, we then regress the estimated quality effects on a constant and the age for which the quality effect has been estimated:

$$
\phi_{a}=\alpha+\zeta \text { age }+e .
$$

The probability limit of the slope coefficient is

$$
\operatorname{plim} \hat{\zeta}=-\frac{\sigma^{2}{ }_{u} \phi}{\sigma_{T}^{2}}
$$

Our age by age estimates are presented in Figure II, together with regression line estimated using this procedure. Our estimate of $\zeta$ is .0000466 , which represents the increment to attenuation bias of estimating quality effects on the next higher age. This bias is small relative to the size of the quality effect, and appears to be a less important source of bias than the measurement error in reported pupil/teacher ratios in 1991.

\section{The Effect of School Quality on Completed Education and Employment}

For at least two reasons, the impact of school quality on returns to education understates the full impact of school quality on earnings in South Africa. School quality has been shown to have a 
large, positive and significant effect on years of completed education (Case and Deaton 1999). In addition, school quality affects the probability of employment for both men and women. In this section, we present estimates of the impact of pupil/teacher ratios both on the years of completed education for men and women aged 24 to 34 , and on the probability of employment. We continue to use the two-stage procedure presented above. In the first stage, we regress years of completed schooling on sets of indicators for district of current residence, marital status, and age, together with indicators for district of origin. We then take the estimated district of origin coefficients, and regress these on the $1991 \mathrm{pupil/teacher} \mathrm{ratio} \mathrm{and} \mathrm{other} \mathrm{district-level} \mathrm{controls.}$

Tables $\mathrm{X}$ and XI present results separately by gender and by age cohort. We find a negative and significant effect of pupil/teacher ratio on years of completed schooling for men and women in each age cohort. When estimating a linear relationship between pupil/teacher ratios and years of completed schooling (the first column for each age cohort), our modal point-estimate of the effect $(-.059)$ is identical to that estimated for cohorts of men born in the United States between 1920 and 1950, (see Card and Krueger (1992), Table 6, columns (7) and (10)), and suggests that reducing the pupil/teacher ratio by 10 students would, all else equal, increase completed schooling by 0.6 years. This result is also identical to that estimated by Case and Deaton, using the 1993 South African Living Standards Survey.

We allow for a non-linear relationship between pupil/teacher ratios and completed schooling (the second column for each cohort), and find the effects are non-linear for both men and women. For example, below a class size of 25 , we find no negative effect of larger class sizes on years of completed education for men aged 24 to 26 . At a class size of 30 , an increase in class size by one student, on average, is associated with a reduction in years of completed education of 
2-hundredths of a year; at a class size of 50 , an increase by one student is associated with a reduction of 11-hundredths of a year.

Years of completed schooling of older adults in the respondent's magisterial district of origin has a positive and significant effect on the schooling of younger adults. This effect is more pronounced for women than for men, and is larger before instrumenting for school quality in 1991 using the 1996 measure. As in Section III above, instrumenting the 1991 measure of school quality with the 1996 measure increases the estimated effects of school quality, and the effect of older adult education is reduced by roughly a third for men.

Tables XII and XIII report the estimated reduced form effects of school quality on the probability of employment for African men and women aged 24 to 34 . For men, we find a small negative effect of pupil/teacher ratios on the probability of employment. For men the estimated effect becomes smaller the older the age cohort, and for men aged 33 to 34 we find no effect of school quality on the probability of employment.

For women, we find a much larger effect of school quality on the probability of employment at each age. Estimating a linear relationship (column 1 for each cohort), we find that an increase in the pupil/teacher ratio of 10 students per class reduces the probability of employment by roughly five percent, with the effect slightly larger at older ages. Again, the impact appears to be non-linear. Below a pupil/teacher ratio of 32, we find no negative effect of pupil/teacher ratios on the probability of employment for women aged 24 to 26,27 to 29 , or 30 to 32. It is possible that the less-significant response of women's returns to education to the pupil/teacher ratio, found in Section III above, is because the selection into employment for women is more sensitive to school quality. The impact of school quality on the probability of 
employment is two to three times as large for women as it is for men, depending upon the specification and cohort.

\section{Conclusions}

The South African Apartheid system continues to profoundly influence the life chances of many Black Africans, through its long lasting effects on the country's education system. Many Black Africans currently in the labor force attended schools with inadequately trained teachers, insufficient textbooks, and pupil-teacher ratios above 80 children per class. We find three channels through which deprivation in school resources affects the outcomes of an entire generation of Black South Africans: educational attainment, probability of employment, and returns to education.

\section{References}

Card, David and Alan Krueger, 1992, "Does school quality matter? Returns to education and the characteristics of public schools in the United States," Journal of Political Economy, 100, 1-40.

Card, David and Alan Krueger, 1996, "Labor market effects of school quality: Theory and evidence," Industrial Relations Section Working Paper \#357, Princeton University, January 1996.

Case, Anne and Angus Deaton, 1999, "School inputs and educational outcomes in South Africa," Quarterly Journal of Economics 114, 1047-1084.

Hanushek, Eric A., 1974, "Efficient estimators for regressing regression coefficients," The American Statistician 28, 66-67. 1996, "Interpreting recent research on schooling in developing countries," World Bank Research Observer, 10, 227-46. 
Hanushek, Eric A., Steven G. Rivkin, and Lori L. Taylor, 1996, “Aggregation and the estimated effects of school resources," The Review of Economics and Statistics 78, 611-627.

Heckman, James, Anne Layne-Farrar, and Petra Todd, 1996, "Human capital pricing equations with an application to estimating the effect of schooling quality on earnings," The Review of Economics and Statistics 78, 562-610.

Krige, Dulcie, Sandy Cairns, Bulelwa Makalima and Di Scott, 1994, The Education Atlas of South Africa, Durban, Education Foundation.

Lam, David, 1999, "Generating extreme inequality: schooling, earnings, and intergenerational transmission of human capital in South Africa and Brazil," mimeo (August), University of Michigan.

Mwabu, Germano and T. Paul Schultz, 1996, "Wage premia for education and location by gender and race in South Africa," Yale Economic Growth Center Discussion Paper 785, February 1998, New Haven, Yale University.

Thomas, Duncan, 1996, "Education across generations in South Africa," American Economic Review, (papers and proceedings), 86, 330-39. 
Table I Educational Attainment and Returns to Education

Panel A: African Men Ages 24-34

\begin{tabular}{|c|c|c|c|c|c|c|}
\hline Ages: & $\begin{array}{c}\text { Fraction in } \\
\text { School in } 1991 \\
\text { (South African } \\
\text { Census 1991) }\end{array}$ & $\begin{array}{c}\text { Fraction } \\
\text { Employed } 1996\end{array}$ & $\begin{array}{l}\text { Mean Yrs Ed } \\
\text { Not Employed } \\
1996\end{array}$ & $\begin{array}{l}\text { Mean Yrs Ed } \\
\text { Employed } \\
1996\end{array}$ & $\begin{array}{l}\text { Returns to } \\
\text { Educn } \\
\text { Employed } \\
1996\end{array}$ & $\begin{array}{c}\text { Proportion } \\
\text { Migrated } \\
\text { Employed } \\
1996\end{array}$ \\
\hline 24 & .6032 & .43 & 8.0 & 8.5 & $\begin{array}{c}.089 \\
(.003)\end{array}$ & .41 \\
\hline 25 & .4623 & .46 & 7.8 & 8.6 & $\begin{array}{c}.090 \\
(.003)\end{array}$ & .40 \\
\hline 26 & .3958 & .51 & 7.7 & 8.6 & $\begin{array}{c}.096 \\
(.002)\end{array}$ & .40 \\
\hline 27 & .2771 & .54 & 7.5 & 8.7 & $\begin{array}{c}.094 \\
(.002)\end{array}$ & .39 \\
\hline 28 & .1945 & .58 & 7.4 & 8.6 & $\begin{array}{c}.094 \\
(.002)\end{array}$ & .39 \\
\hline 29 & .1368 & .60 & 7.3 & 8.6 & $\begin{array}{c}.101 \\
(.002)\end{array}$ & .40 \\
\hline 30 & .1026 & .60 & 6.8 & 8.4 & $\begin{array}{c}.101 \\
(.002)\end{array}$ & .38 \\
\hline 31 & .0722 & .63 & 6.8 & 8.3 & $\begin{array}{c}.098 \\
(.002)\end{array}$ & .38 \\
\hline 32 & .0520 & .63 & 6.5 & 8.1 & $\begin{array}{c}.094 \\
(.002)\end{array}$ & .39 \\
\hline 33 & .0356 & .63 & 6.3 & 8.0 & $\begin{array}{c}.095 \\
(.002)\end{array}$ & .40 \\
\hline 34 & .0273 & .64 & 6.2 & 7.9 & $\begin{array}{c}.096 \\
(.002)\end{array}$ & .39 \\
\hline
\end{tabular}

Notes: The fraction in school in 1991 is estimated using the 100\% 1991 South African census, which included all of South Africa except the "independent homelands" of Transkei, Ciskei, Bophutatswana and Venda. All other statistics in Table I come from the 10\% 1996 South African census, which included all South Africans. Estimates in Table I for the1996 sample are restricted to Black men and women who report that they are employed or not employed and not in school. We define a respondent as "employed" if they have answered "yes" to the question: "Does (this person) work? (For pay, profit or family gain.)" The questionnaire notes that all formal and informal employment is to be covered.

Returns to education are from OLS regressions of $\log$ (annual earnings) on years of completed education, one regression for each age and sex, with a constant term included but not reported. Standard errors reported in parentheses. 


\section{Table I Educational Attainment and Returns to Education}

Panel B: African Women Ages 24-34

\begin{tabular}{|c|c|c|c|c|c|c|}
\hline Ages: & $\begin{array}{c}\text { Fraction in } \\
\text { School in } 1991 \\
\text { (South African } \\
\text { Census 1991) }\end{array}$ & $\begin{array}{c}\text { Fraction } \\
\text { Employed } 1996\end{array}$ & $\begin{array}{c}\text { Mean Yrs Ed } \\
\text { Not Employed } \\
1996\end{array}$ & $\begin{array}{l}\text { Mean Yrs Ed } \\
\text { Employed } \\
1996\end{array}$ & $\begin{array}{l}\text { Returns to } \\
\text { Educn } \\
\text { Employed } \\
1996\end{array}$ & $\begin{array}{c}\text { Proportion } \\
\text { Migrated } \\
\text { Employed } \\
1996\end{array}$ \\
\hline 24 & .5906 & .22 & 8.1 & 9.0 & $\begin{array}{l}.135 \\
(.004)\end{array}$ & .34 \\
\hline 25 & .4387 & .26 & 8.0 & 9.1 & $\begin{array}{l}.140 \\
(.004)\end{array}$ & .35 \\
\hline 26 & .3678 & .27 & 7.8 & 9.2 & $\begin{array}{l}.141 \\
(.003)\end{array}$ & .34 \\
\hline 27 & .2835 & .29 & 7.7 & 9.1 & $\begin{array}{l}.136 \\
(.003)\end{array}$ & .35 \\
\hline 28 & .2166 & .32 & 7.5 & 9.1 & $\begin{array}{l}.141 \\
(.003)\end{array}$ & .35 \\
\hline 29 & .1662 & .33 & 7.4 & 9.1 & $\begin{array}{c}.148 \\
(.003)\end{array}$ & .35 \\
\hline 30 & .1179 & .34 & 6.8 & 8.7 & $\begin{array}{l}.143 \\
(.003)\end{array}$ & .33 \\
\hline 31 & .0938 & .36 & 6.8 & 8.9 & $\begin{array}{l}.144 \\
(.003)\end{array}$ & .35 \\
\hline 32 & .0738 & .37 & 6.6 & 8.6 & $\begin{array}{l}.141 \\
(.003)\end{array}$ & .33 \\
\hline 33 & .0560 & .38 & 6.4 & 8.4 & $\begin{array}{l}.142 \\
(.003)\end{array}$ & .33 \\
\hline 34 & .0490 & .38 & 6.1 & 8.3 & $\begin{array}{c}.148 \\
(.003)\end{array}$ & .35 \\
\hline
\end{tabular}

Notes: The fraction in school in 1991 is estimated using the 100\% 1991 South African census, which included all of South Africa except the "independent homelands" of Transkei, Ciskei, Bophutatswana and Venda. All other statistics in Table I come from the 10\% 1996 South African census, which included all South Africans. Estimates in Table I for the1996 sample are restricted to Black men and women who report that they are employed or not employed and not in school. We define a respondent as "employed" if they have answered "yes" to the question: "Does (this person) work? (For pay, profit or family gain.)" The questionnaire notes that all formal and informal employment is to be covered.

Returns to education are from OLS regressions of log(annual earnings) on years of completed education, one regression for each age and sex, with a constant term included but not reported. Standard errors reported in parentheses. 
Table II

Determinants of Returns to Education By Magisterial District of Origin

School Quality Measures from the Education Atlas 1991

Second stage regression results, African Men 24-34

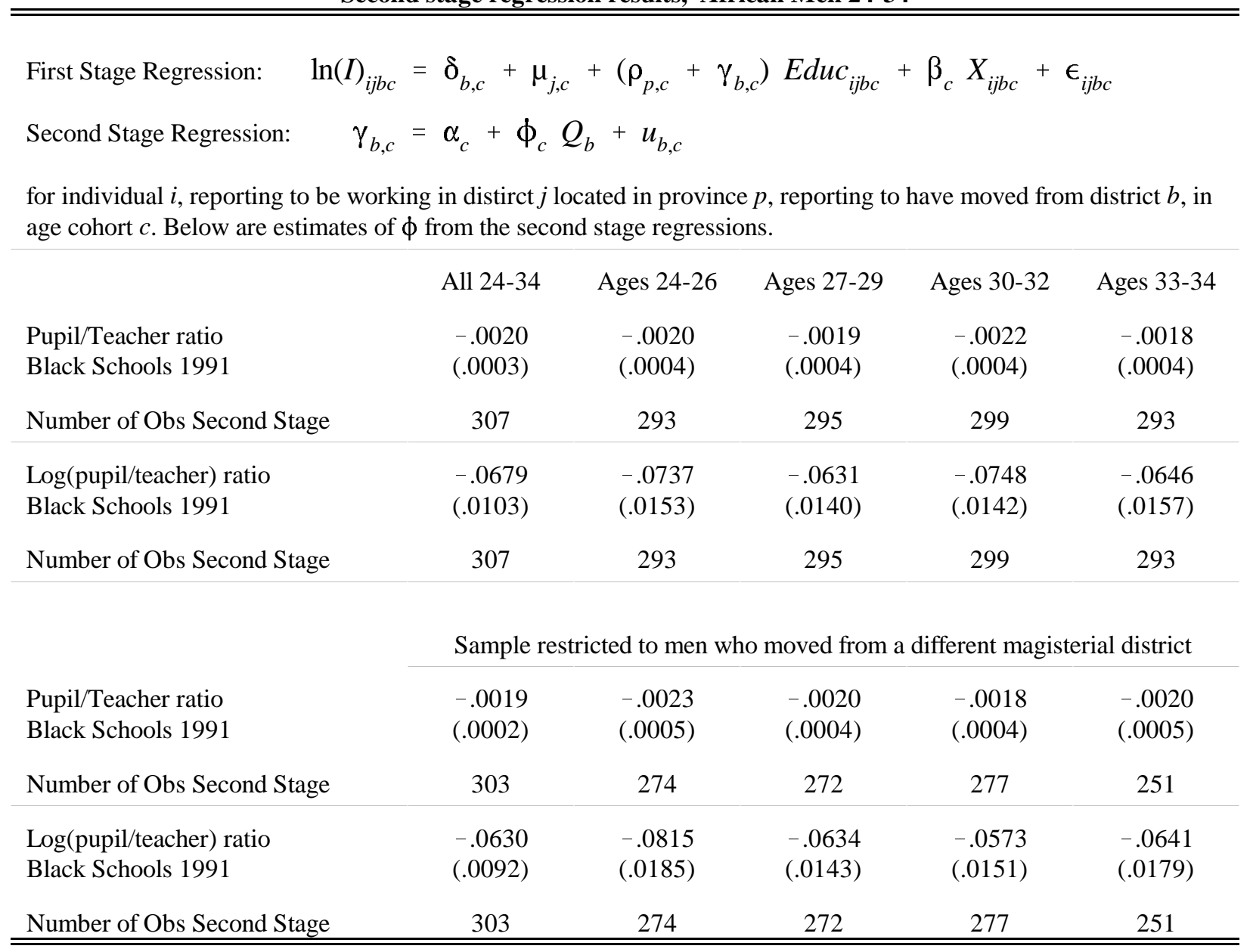

Notes: Standard errors in parentheses. All second-stage regressions include a constant term (not reported). Both the first and second stages are run separately by age cohort. In the first-stage regression, $\ln (\mathrm{I})$ is annual reported income, Educ is years of completed education, $\mathrm{X}$ are personal characteristics (here, marital status) and Q is a measure of school quality in the magisterial district the person reports having migrated from. All regressions are weighted least squares, using the inverse of the sampling variances of the estimated returns from the first stage as weights. 
Table III

Determinants of Returns to Education By Magisterial District of Previous Residency School Quality Measures from the Education Atlas 1991

Second stage regression results, African Women 24-34

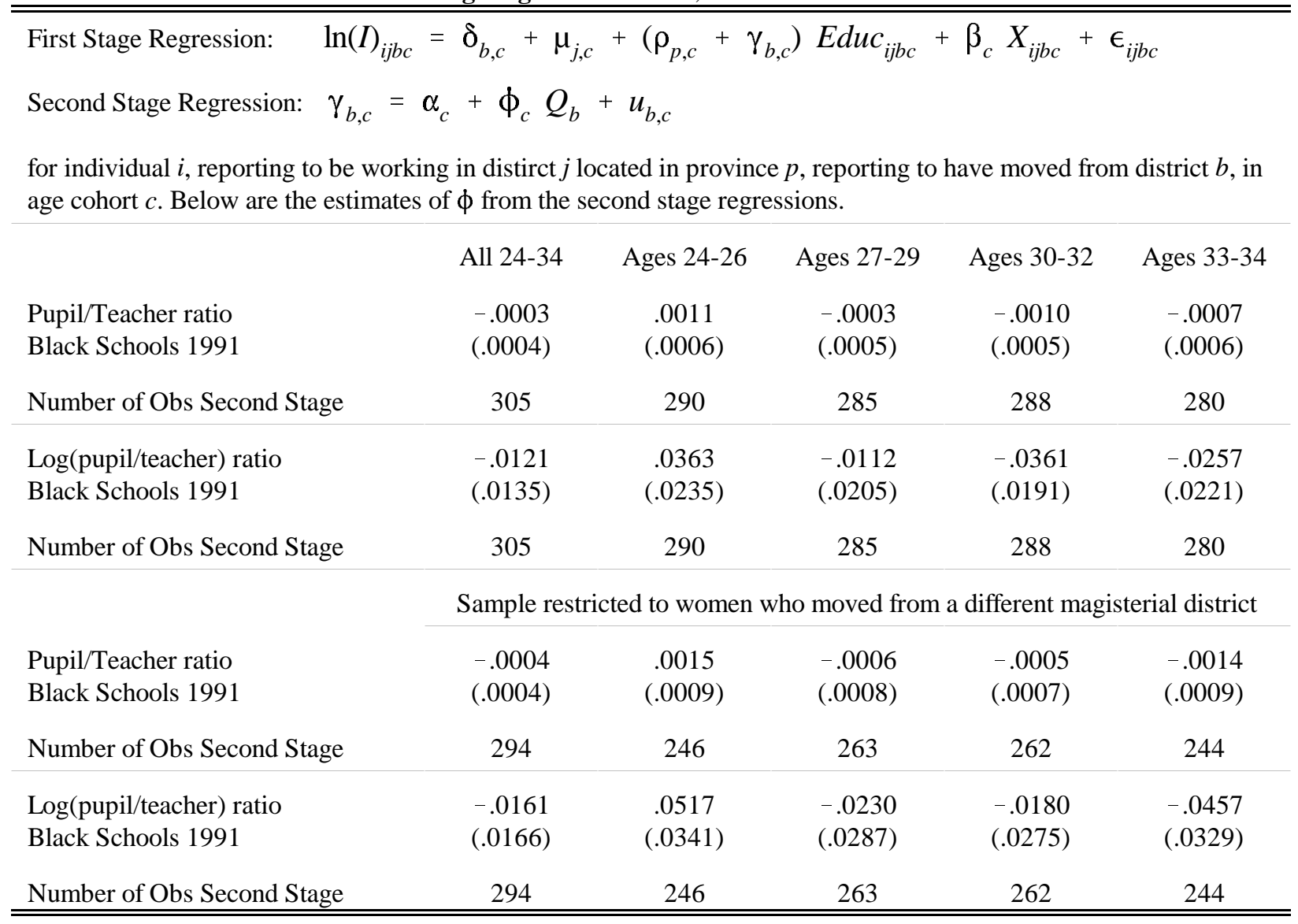

Notes: Standard errors in parentheses. All second stage regressions include a constant term (not reported). In the firststage regression, $\ln (\mathrm{I})$ is annual reported income, Educ is years of completed education, $\mathrm{X}$ are personal characteristics (here, marital status) and Q is a measure of school quality in the magisterial district the person reports having migrated from. All regressions are weighted least squares, using the inverse of the sampling variances of the estimated returns from the first stage as weights. 
Table IV

Additional Determinants of Returns to Education

African Men 24-34

\begin{tabular}{|c|c|c|c|c|c|c|c|c|c|c|c|c|}
\hline \multirow[b]{2}{*}{$\begin{array}{l}\text { Pupil/Teacher Ratio } \\
1991\end{array}$} & \multicolumn{3}{|c|}{$24-26$} & \multicolumn{3}{|c|}{$27-29$} & \multicolumn{3}{|c|}{$30-32$} & \multicolumn{3}{|c|}{$33-34$} \\
\hline & $\begin{array}{l}-.0018 \\
(.0005)\end{array}$ & $\begin{array}{l}-.0021 \\
(.0004)\end{array}$ & $\begin{array}{l}-.0020 \\
(.0004)\end{array}$ & $\begin{array}{l}-.0019 \\
(.0005)\end{array}$ & $\begin{array}{l}-.0019 \\
(.0004)\end{array}$ & $\begin{array}{l}-.0019 \\
(.0004)\end{array}$ & $\begin{array}{l}-.0020 \\
(.0005)\end{array}$ & $\begin{array}{l}-.0023 \\
(.0004)\end{array}$ & $\begin{array}{l}-.0023 \\
(.0004)\end{array}$ & $\begin{array}{l}-.0021 \\
(.0005)\end{array}$ & $\begin{array}{l}-.0019 \\
(.0004)\end{array}$ & $\begin{array}{l}-.0018 \\
(.0004)\end{array}$ \\
\hline $\begin{array}{l}\text { Propn of Teachers } \\
\text { without Std } 10\end{array}$ & $\begin{array}{l}.0116 \\
(.0227)\end{array}$ & -- & -- & $\begin{array}{c}.0364 \\
(.0238)\end{array}$ & -- & -- & $\begin{array}{c}.0463 \\
(.0240)\end{array}$ & -- & -- & $\begin{array}{l}-.0216 \\
(.0266)\end{array}$ & -- & -- \\
\hline Aequate textbooks & -- & $\begin{array}{c}.0071 \\
(.0128)\end{array}$ & -- & -- & $\begin{array}{l}-.0282 \\
(.0131)\end{array}$ & -- & -- & $\begin{array}{l}-.0051 \\
(.0130)\end{array}$ & -- & -- & $\begin{array}{c}.0100 \\
(.0143)\end{array}$ & -- \\
\hline $\begin{array}{l}\text { Mean Education of } \\
\text { Adults 49-59 }\end{array}$ & -- & -- & $\begin{array}{l}-.0000 \\
(.0014)\end{array}$ & -- & -- & $\begin{array}{c}.0028 \\
(.0014)\end{array}$ & -- & -- & $\begin{array}{c}.0002 \\
(.0014)\end{array}$ & -- & -- & $\begin{array}{c}.0004 \\
(.0015)\end{array}$ \\
\hline Number of Obs & 249 & 293 & 281 & 251 & 295 & 286 & 255 & 299 & 287 & 250 & 293 & 284 \\
\hline
\end{tabular}

Table V

Additional Determinants of Returns to Education

African Women 24-34

\begin{tabular}{|c|c|c|c|c|c|c|c|c|c|c|c|c|}
\hline \multirow[b]{2}{*}{$\begin{array}{l}\text { Pupil/Teacher Ratio } \\
1991\end{array}$} & \multicolumn{3}{|c|}{$24-26$} & \multicolumn{3}{|c|}{$27-29$} & \multicolumn{3}{|c|}{$30-32$} & \multicolumn{3}{|c|}{$33-34$} \\
\hline & $\begin{array}{c}.0005 \\
(.0008)\end{array}$ & $\begin{array}{c}.0007 \\
(.0006)\end{array}$ & $\begin{array}{c}.0016 \\
(.0006)\end{array}$ & $\begin{array}{l}-.0005 \\
(.0007)\end{array}$ & $\begin{array}{l}-.0003 \\
(.0005)\end{array}$ & $\begin{array}{l}-.0000 \\
(.0005)\end{array}$ & $\begin{array}{l}-.0010 \\
(.0006)\end{array}$ & $\begin{array}{l}-.0009 \\
(.0005)\end{array}$ & $\begin{array}{l}-.0005 \\
(.0005)\end{array}$ & $\begin{array}{l}-.0012 \\
(.0007)\end{array}$ & $\begin{array}{l}-.0008 \\
(.0006)\end{array}$ & $\begin{array}{l}-.0004 \\
(.0006)\end{array}$ \\
\hline $\begin{array}{l}\text { Propn of Teachers } \\
\text { without Std } 10\end{array}$ & $\begin{array}{l}-.0353 \\
(.0363)\end{array}$ & -- & -- & $\begin{array}{l}-.0542 \\
(.0329)\end{array}$ & -- & -- & $\begin{array}{l}-.0241 \\
(.0307)\end{array}$ & -- & -- & $\begin{array}{l}-.0120 \\
(.0373)\end{array}$ & -- & -- \\
\hline Adequate textbooks & -- & $\begin{array}{l}-.0186 \\
(.0211)\end{array}$ & -- & -- & $\begin{array}{l}-.0401 \\
(.0182)\end{array}$ & -- & -- & $\begin{array}{l}-.0219 \\
(.0168)\end{array}$ & -- & -- & $\begin{array}{l}-.0227 \\
(.0202)\end{array}$ & -- \\
\hline $\begin{array}{l}\text { Mean Education } \\
\text { Adults 49-59 }\end{array}$ & -- & -- & $\begin{array}{c}.0106 \\
(.0022)\end{array}$ & -- & -- & $\begin{array}{c}.0074 \\
(.0018)\end{array}$ & -- & -- & $\begin{array}{l}.0084 \\
(.0017)\end{array}$ & -- & -- & $\begin{array}{c}.0074 \\
(.0020)\end{array}$ \\
\hline Number of Obs & 247 & 290 & 279 & 243 & 285 & 277 & 246 & 288 & 280 & 238 & 280 & 273 \\
\hline
\end{tabular}


Table VI

Estimating the Impact of School Quality by Educational Attainment

\begin{tabular}{lcc}
\hline \hline & \multicolumn{2}{c}{ African Men Aged 24-34 } \\
& Years of Educ 2-11 & Years of Educ 12-18 \\
Pupil/Teacher Ratio 1991 & -.0018 & -.0019 \\
& $(.0004)$ & $(.0014)$ \\
Number of Obs 2nd Stage & 306 & 265 \\
& Observations 1st & Observations 1st \\
stage=51334 & African Women Aged 24-34 \\
Pupil/Teacher Ratio 1991 & -.0006 & .0007 \\
& $(.0005)$ & $(.0015)$ \\
Number of Obs 2nd Stage & 301 & 263 \\
& Observations 1st & Observations 1st \\
& stage=30567 & stage=16770 \\
\hline \hline
\end{tabular}

Notes: Weighted least squares estimates, with the inverse sampling weights on the returns to education used as weights in the second stage. Standard errors in parentheses. 
Table VII

Panel A: Allowing Returns-to-Education-by-District-of-Origin to Vary by Province of Employment African Men Aged 24 to 34

\begin{tabular}{|c|c|c|c|c|c|c|c|c|c|}
\hline & $\begin{array}{l}\text { Western } \\
\text { Cape }\end{array}$ & $\begin{array}{l}\text { Eastern } \\
\text { Cape }\end{array}$ & $\begin{array}{c}\text { Northern } \\
\text { Cape }\end{array}$ & Free State & $\begin{array}{l}\text { KwaZulu- } \\
\text { Natal }\end{array}$ & Northwest & Gauteng & Mpumalanga & Northern \\
\hline $\begin{array}{l}\text { Pupil/Teacher } \\
\text { Ratio } 1991\end{array}$ & $\begin{array}{l}-.0020 \\
(.0010)\end{array}$ & $\begin{array}{c}.0010 \\
(.0007)\end{array}$ & $\begin{array}{c}.0002 \\
(.0012)\end{array}$ & $\begin{array}{l}-.0041 \\
(.0006)\end{array}$ & $\begin{array}{l}-.0015 \\
(.0004)\end{array}$ & $\begin{array}{l}-.0013 \\
(.0004)\end{array}$ & $\begin{array}{l}-.0008 \\
(.0003)\end{array}$ & $\begin{array}{l}-.0020 \\
(.0007)\end{array}$ & $\begin{array}{l}-.0008 \\
(.0012)\end{array}$ \\
\hline $\begin{array}{l}\text { Number Obs } \\
\text { 2nd stage }\end{array}$ & 114 & 91 & 31 & 152 & 101 & 138 & 233 & 112 & 68 \\
\hline $\begin{array}{c}\text { Number Obs } \\
\text { 1st stage }\end{array}$ & 2661 & 6276 & 950 & 9071 & 11159 & 6600 & 24577 & 7099 & 2810 \\
\hline
\end{tabular}

Panel B: Allowing Returns-to-Education-by-District-of-Origin to Vary by Region of Employment African Men Aged 24 to 34

\begin{tabular}{|c|c|c|c|c|}
\hline & $\begin{array}{l}\text { Western, Eastern and } \\
\text { Northern Cape }\end{array}$ & $\begin{array}{l}\text { Free State and } \\
\quad \text { Gauteng }\end{array}$ & $\begin{array}{c}\text { Mpumalanga, } \\
\text { Northern and } \\
\text { Northwest }\end{array}$ & $\begin{array}{c}\text { KwaZulu- } \\
\text { Natal }\end{array}$ \\
\hline $\begin{array}{l}\text { Pupil/Teacher } \\
\text { Ratio } 1991\end{array}$ & $\begin{array}{c}.0005 \\
(.0005)\end{array}$ & $\begin{array}{l}-.0013 \\
(.0004)\end{array}$ & $\begin{array}{l}-.0015 \\
(.0004)\end{array}$ & $\begin{array}{l}-.0015 \\
(.0004)\end{array}$ \\
\hline $\begin{array}{l}\text { Number Obs } \\
\text { 2nd stage }\end{array}$ & 156 & 259 & 196 & 101 \\
\hline $\begin{array}{l}\text { Number Obs } \\
\text { 1st stage }\end{array}$ & 9887 & 33648 & 16509 & 11159 \\
\hline
\end{tabular}




\section{Table VIII}

Panel A: Estimating Non-linearities in the Impact of School Quality

African Men 24-34

\begin{tabular}{|c|c|c|c|c|c|c|c|c|c|c|c|c|}
\hline \multirow[b]{2}{*}{ Pupil/Teacher Ratio 1991} & \multicolumn{3}{|c|}{$24-26$} & \multicolumn{3}{|c|}{$27-29$} & \multicolumn{3}{|c|}{$30-32$} & \multicolumn{3}{|c|}{$33-34$} \\
\hline & $\begin{array}{l}-.0020 \\
(.0004)\end{array}$ & -- & $\begin{array}{l}-.0008 \\
(.0025)\end{array}$ & $\begin{array}{l}-.0019 \\
(.0004)\end{array}$ & -- & $\begin{array}{l}-.0003 \\
(.0021)\end{array}$ & $\begin{array}{l}-.0022 \\
(.0004)\end{array}$ & -- & $\begin{array}{l}-.0011 \\
(.0022)\end{array}$ & $\begin{array}{l}-.0018 \\
(.0004)\end{array}$ & -- & $\begin{array}{l}-.0026 \\
(.0025)\end{array}$ \\
\hline $\begin{array}{l}\text { Pupil/Teacher Ratio }{ }^{2} 1991 \\
\text { (times } 10^{-4} \text { ) }\end{array}$ & -- & $\begin{array}{l}-.228 \\
(.044)\end{array}$ & $\begin{array}{l}-.131 \\
(.291)\end{array}$ & -- & $\begin{array}{l}-.228 \\
(.044)\end{array}$ & $\begin{array}{l}-.189 \\
(.253)\end{array}$ & -- & $\begin{array}{l}-.272 \\
(.047)\end{array}$ & $\begin{array}{l}-.137 \\
(.265)\end{array}$ & -- & $\begin{array}{l}-.205 \\
(.050)\end{array}$ & $\begin{array}{c}.098 \\
(.297)\end{array}$ \\
\hline $\begin{array}{l}F \text {-test: joint significance } \\
\text { Pupil/Teacher and its square }\end{array}$ & -- & -- & $\begin{array}{l}13.16 \\
(.0000)\end{array}$ & -- & -- & $\begin{array}{l}13.00 \\
(.0000)\end{array}$ & -- & -- & $\begin{array}{c}16.62 \\
(.0000)\end{array}$ & -- & -- & $\begin{array}{c}9.01 \\
(.0002)\end{array}$ \\
\hline Number of Obs 2nd Stage & 293 & 293 & 293 & 295 & 295 & 295 & 299 & 299 & 299 & 293 & 293 & 293 \\
\hline
\end{tabular}

Panel B: Estimating Non-linearities in the Impact of School Quality

\begin{tabular}{lllllllllll}
\multicolumn{1}{c}{ Panel B: Estimating Non-linearities in the Impact of School Quality } \\
African Women 24-34
\end{tabular}

Notes: Standard errors in parentheses, with p-values given under $F$-tests. 
Table IX

Estimating the Impact of School Quality on Returns to Education

\section{Instrumenting the 1991 Pupil/Teacher Ratio}

\begin{tabular}{|c|c|c|c|c|c|c|c|c|}
\hline \multicolumn{9}{|c|}{ Men } \\
\hline & \multicolumn{2}{|c|}{$24-26$} & \multicolumn{2}{|c|}{$27-29$} & \multicolumn{2}{|c|}{$30-32$} & \multicolumn{2}{|c|}{$33-34$} \\
\hline & OLS & TSLS & OLS & TSLS & OLS & TSLS & OLS & TSLS \\
\hline $\begin{array}{l}\text { Pupil/Teacher Ratio } \\
\text { Black Schools } 1991\end{array}$ & $\begin{array}{l}-.0020 \\
(.0004)\end{array}$ & $\begin{array}{l}-.0023 \\
(.0006)\end{array}$ & $\begin{array}{l}-.0019 \\
(.0004)\end{array}$ & $\begin{array}{l}-.0026 \\
(.0006)\end{array}$ & $\begin{array}{l}-.0022 \\
(.0004)\end{array}$ & $\begin{array}{l}-.0033 \\
(.0006)\end{array}$ & $\begin{array}{l}-.0018 \\
(.0004)\end{array}$ & $\begin{array}{l}-.0031 \\
(.0007)\end{array}$ \\
\hline Number of Obs & 293 & 293 & 295 & 295 & 299 & 299 & 293 & 293 \\
\hline \multicolumn{9}{|c|}{ Women } \\
\hline & \multicolumn{2}{|c|}{$24-26$} & \multicolumn{2}{|c|}{$27-29$} & \multicolumn{2}{|c|}{$30-32$} & \multicolumn{2}{|c|}{$33-34$} \\
\hline & OLS & TSLS & OLS & TSLS & OLS & TSLS & OLS & TSLS \\
\hline $\begin{array}{l}\text { Pupil/Teacher Ratio } \\
\text { Black Schools } 1991\end{array}$ & $\begin{array}{c}.0011 \\
(.0006)\end{array}$ & $\begin{array}{c}.0009 \\
(.0010)\end{array}$ & $\begin{array}{l}-.0003 \\
(.0005)\end{array}$ & $\begin{array}{l}-.0018 \\
(.0009)\end{array}$ & $\begin{array}{l}-.0010 \\
(.0005)\end{array}$ & $\begin{array}{l}-.0012 \\
(.0008)\end{array}$ & $\begin{array}{l}-.0007 \\
(.0006)\end{array}$ & $\begin{array}{l}-.0003 \\
(.0010)\end{array}$ \\
\hline Number of Obs & 290 & 290 & 285 & 285 & 288 & 288 & 280 & 280 \\
\hline
\end{tabular}

Notes: Standard errors in parentheses. Weighted least squares estimation using the inverse of the first stage sampling variance as weights. The two-stage least squares estimates instrument the 1991 Pupil/Teacher ratio using the 1996 pupil-weighted median learner/educator ratio from the 1996 School Register of Needs.

The first stage regression when all magisterial districts with observations in both 1991 and 1996 are present is:

$$
P T_{1991}=22.07+0.5014 \text { Median } P T_{1996}
$$

(Number of observations $=308$. Standard errors presented in parentheses.) 
Table $\mathrm{X}$

The Effects of School Quality on Years of Completed Schooling

African Men

\begin{tabular}{|c|c|c|c|c|c|c|c|c|}
\hline \multirow[b]{2}{*}{$\begin{array}{l}\text { Pupil/Teacher Ratio } \\
1991\end{array}$} & \multicolumn{2}{|c|}{$24-26$} & \multicolumn{2}{|c|}{$27-29$} & \multicolumn{2}{|c|}{$30-32$} & \multicolumn{2}{|c|}{$33-34$} \\
\hline & $\begin{array}{l}-.0697 \\
(.0076)\end{array}$ & $\begin{array}{l}.1083 \\
(.0437)\end{array}$ & $\begin{array}{l}-.0755 \\
(.0080)\end{array}$ & $\begin{array}{l}.1290 \\
(.0442)\end{array}$ & $\begin{array}{l}-.0590 \\
(.0080)\end{array}$ & $\begin{array}{c}.0909 \\
(.0445)\end{array}$ & $\begin{array}{l}-.0585 \\
(.0084)\end{array}$ & $\begin{array}{c}.0509 \\
(.0461)\end{array}$ \\
\hline PT Ratio 2 & -- & $\begin{array}{l}-.0022 \\
(.0005)\end{array}$ & -- & $\begin{array}{l}-.0025 \\
(.0005)\end{array}$ & -- & $\begin{array}{l}-.0018 \\
(.0005)\end{array}$ & -- & $\begin{array}{l}-.0014 \\
(.0006)\end{array}$ \\
\hline $\begin{array}{l}\text { F-test joint } \\
\text { significance }\end{array}$ & -- & 52.91 & -- & 58.38 & -- & 34.05 & -- & 27.57 \\
\hline Number of Obs & 304 & 304 & 301 & 301 & 305 & 305 & 298 & 298 \\
\hline
\end{tabular}

African Men

\begin{tabular}{lccccccccc}
\hline \hline & \multicolumn{2}{c}{$24-26$} & \multicolumn{2}{c}{$27-29$} & & \multicolumn{2}{c}{$30-32$} & & $33-34$ \\
& OLS & TSLS & OLS & TSLS & OLS & TSLS & OLS & TSLS \\
& & & & & & & & & \\
& & & & & & & & \\
Pupil/Teacher Ratio & -.0658 & -.1223 & -.0688 & -.1254 & -.0464 & -.1023 & -.0484 & -.0828 \\
Black Schools 1991 & $(.0079)$ & $(.0139)$ & $(.0083)$ & $(.0144)$ & $(.0079)$ & $(.0139)$ & $(.0083)$ & $(.0139)$ \\
Mean Years of Educ & .0303 & -.0136 & .0730 & .0304 & .1573 & .1137 & .1426 & .1151 \\
Adults 49-59 & $(.0270)$ & $(.0306)$ & $(.0285)$ & $(.0319)$ & $(.0273)$ & $(.0307)$ & $(.0297)$ & $(.0318)$ \\
Number of Obs & 291 & 291 & 289 & 289 & 292 & 292 & 286 & 286 \\
\hline \hline
\end{tabular}

Notes: Standard errors in parentheses. Weighted least squares, with inverse sampling variances from the first stage used as weights. Two-stage least squares estimates use the 1996 pupil-weighted median learner/educator ratio as an instrument for the average pupil/teacher ratio in Black schools in 1991. The first stage regression when all magisterial districts with observations in both 1991 and 1996 are present is:

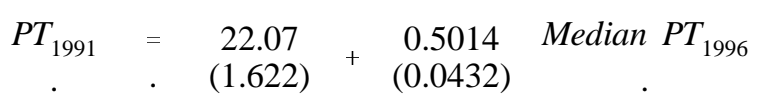

(Number of observations $=308$. Standard errors presented in parentheses.) 
Table XI

Reduced Form Estimates of the Effects of School Quality on Years of Completed Schooling African Women

\begin{tabular}{|c|c|c|c|c|c|c|c|c|}
\hline \multirow[b]{2}{*}{$\begin{array}{l}\text { Pupil/Teacher Ratio } \\
1991\end{array}$} & \multicolumn{2}{|c|}{$24-26$} & \multicolumn{2}{|c|}{$27-29$} & \multicolumn{2}{|c|}{$30-32$} & \multicolumn{2}{|c|}{$33-34$} \\
\hline & $\begin{array}{l}-.0509 \\
(.0065)\end{array}$ & $\begin{array}{l}.1063 \\
(.0380)\end{array}$ & $\begin{array}{l}-.0590 \\
(.0074)\end{array}$ & $\begin{array}{l}.0404 \\
(.0424)\end{array}$ & $\begin{array}{l}-.0561 \\
(.0080)\end{array}$ & $\begin{array}{l}.0270 \\
(.0458)\end{array}$ & $\begin{array}{l}-.0424 \\
(.0100)\end{array}$ & $\begin{array}{l}-.0159 \\
(.0571)\end{array}$ \\
\hline PT Ratio ${ }^{2}$ & -- & $\begin{array}{l}-.0019 \\
(.0005)\end{array}$ & -- & $\begin{array}{l}-.0012 \\
(.0005)\end{array}$ & -- & $\begin{array}{l}-.0010 \\
(.0006)\end{array}$ & -- & $\begin{array}{l}-.0003 \\
(.0007)\end{array}$ \\
\hline $\begin{array}{l}\text { F-test joint } \\
\text { significance }\end{array}$ & -- & 40.96 & -- & 35.43 & -- & 26.41 & -- & 9.17 \\
\hline Number of Obs & 306 & 306 & 301 & 301 & 302 & 302 & 293 & 293 \\
\hline
\end{tabular}

\begin{tabular}{lccccccccc}
\hline \hline & \multicolumn{2}{c}{$24-26$} & \multicolumn{2}{c}{$27-29$} & & \multicolumn{2}{c}{$30-32$} & & $33-34$ \\
& OLS & TSLS & OLS & TSLS & OLS & TSLS & OLS & TSLS \\
& & & & & & & & \\
& & & & & & & & \\
Pupil/Teacher Ratio & -.0419 & -.0771 & -.0493 & -.0863 & -.0388 & -.0785 & -.0233 & -.0424 \\
1991 & $(.0064)$ & $(.0110)$ & $(.0073)$ & $(.0124)$ & $(.0071)$ & $(.0123)$ & $(.0088)$ & $(.0150)$ \\
Mean Years of Educ & .1134 & .0877 & .1497 & .1217 & .2603 & .2290 & .3044 & .2896 \\
Adults 49-59 & $(.0218)$ & $(.0238)$ & $(.0251)$ & $(.0273)$ & $(.0246)$ & $(.0270)$ & $(.0301)$ & $(.0318)$ \\
Number of Obs & 293 & 293 & 289 & 289 & 290 & 290 & 282 & 282 \\
\hline \hline
\end{tabular}


Table XII

The Effects of School Quality on the Probability of Employment

African Men

\begin{tabular}{|c|c|c|c|c|c|c|c|c|}
\hline \multirow[b]{2}{*}{$\begin{array}{l}\text { Pupil/Teacher Ratio } \\
1991\end{array}$} & \multicolumn{2}{|c|}{$24-26$} & \multicolumn{2}{|c|}{$27-29$} & \multicolumn{2}{|c|}{$30-32$} & \multicolumn{2}{|c|}{$33-34$} \\
\hline & $\begin{array}{l}-.0023 \\
(.0008)\end{array}$ & $\begin{array}{l}-.0013 \\
(.0047)\end{array}$ & $\begin{array}{l}-.0030 \\
(.0008)\end{array}$ & $\begin{array}{l}-.0077 \\
(.0045)\end{array}$ & $\begin{array}{l}-.0021 \\
(.0007)\end{array}$ & $\begin{array}{l}-.0069 \\
(.0038)\end{array}$ & $\begin{array}{l}-.0004 \\
(.0008)\end{array}$ & $\begin{array}{l}-.0079 \\
(.0044)\end{array}$ \\
\hline PT Ratio ${ }^{2}$ & -- & $\begin{array}{l}-.0000 \\
(.0001)\end{array}$ & -- & $\begin{array}{l}.0001 \\
(.0001)\end{array}$ & -- & $\begin{array}{c}.00006 \\
(.00004)\end{array}$ & -- & $\begin{array}{c}.0001 \\
(.0001)\end{array}$ \\
\hline $\begin{array}{l}\text { F-test joint } \\
\text { significance }\end{array}$ & -- & 4.10 & -- & 7.72 & -- & 5.64 & -- & 1.68 \\
\hline Number of Obs & 303 & 303 & 301 & 301 & 305 & 305 & 298 & 298 \\
\hline \multicolumn{9}{|c|}{ African Men } \\
\hline & \multicolumn{2}{|c|}{$24-26$} & \multicolumn{2}{|c|}{$27-29$} & \multicolumn{2}{|c|}{$30-32$} & \multicolumn{2}{|c|}{$33-34$} \\
\hline & OLS & TSLS & OLS & TSLS & OLS & TSLS & OLS & TSLS \\
\hline $\begin{array}{l}\text { Pupil/Teacher Ratio } \\
\text { Black Schools } 1991\end{array}$ & $\begin{array}{l}-.0028 \\
(.0008)\end{array}$ & $\begin{array}{l}-.0045 \\
(.0014)\end{array}$ & $\begin{array}{l}-.0031 \\
(.0008)\end{array}$ & $\begin{array}{l}-.0006 \\
(.0014)\end{array}$ & $\begin{array}{l}-.0020 \\
(.0007)\end{array}$ & $\begin{array}{l}-.0032 \\
(.0011)\end{array}$ & $\begin{array}{l}-.0002 \\
(.0008)\end{array}$ & $\begin{array}{l}.0013 \\
(.0013)\end{array}$ \\
\hline $\begin{array}{l}\text { Mean Years of Educ } \\
\text { Adults } 49-59\end{array}$ & $\begin{array}{l}-.0067 \\
(.0029)\end{array}$ & $\begin{array}{l}-.0081 \\
(.0030)\end{array}$ & $\begin{array}{l}-.0040 \\
(.0028)\end{array}$ & $\begin{array}{l}-.0021 \\
(.0030)\end{array}$ & $\begin{array}{l}-.0003 \\
(.0024)\end{array}$ & $\begin{array}{l}-.0012 \\
(.0025)\end{array}$ & $\begin{array}{l}.0008 \\
(.0029)\end{array}$ & $\begin{array}{l}.0019 \\
(.0031)\end{array}$ \\
\hline Number of Obs & 290 & 290 & 289 & 289 & 292 & 292 & 286 & 286 \\
\hline
\end{tabular}

Notes: Standard errors in parentheses. Weighted least squares, with inverse sampling variances from the first stage used as weights. Two-stage least squares estimates use the 1996 pupil-weighted median learner/educator ratio as an instrument for the average pupil/teacher ratio in Black schools in 1991. The first stage regression when all magisterial districts with observations in both 1991 and 1996 are present is:

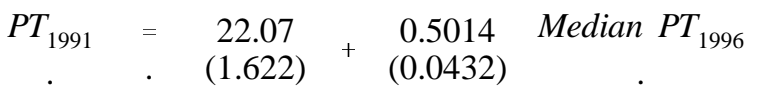

(Number of observations $=308$. Standard errors presented in parentheses.) 


\section{Table XIII}

The Effects of School Quality on the Probability of Employment

African Women

\begin{tabular}{|c|c|c|c|c|c|c|c|c|}
\hline \multirow[b]{2}{*}{$\begin{array}{l}\text { Pupil/Teacher Ratio } \\
1991\end{array}$} & \multicolumn{2}{|c|}{$24-26$} & \multicolumn{2}{|c|}{$27-29$} & \multicolumn{2}{|c|}{$30-32$} & \multicolumn{2}{|c|}{$33-34$} \\
\hline & $\begin{array}{l}-.0037 \\
(.0004)\end{array}$ & $\begin{array}{c}.0078 \\
(.0054)\end{array}$ & $\begin{array}{l}-.0047 \\
(.0009)\end{array}$ & $\begin{array}{c}.0010 \\
(.0052)\end{array}$ & $\begin{array}{l}-.0054 \\
(.0009)\end{array}$ & $\begin{array}{l}.0064 \\
(.0054)\end{array}$ & $\begin{array}{l}-.0063 \\
(.0011)\end{array}$ & $\begin{array}{l}-.0003 \\
(.0064)\end{array}$ \\
\hline PT Ratio ${ }^{2}$ & -- & $\begin{array}{l}-.0001 \\
(.0001)\end{array}$ & -- & $\begin{array}{l}-.0001 \\
(.0001)\end{array}$ & -- & $\begin{array}{l}-.0001 \\
(.0001)\end{array}$ & -- & $\begin{array}{l}-.0001 \\
(.0001)\end{array}$ \\
\hline $\begin{array}{l}\text { F-test joint } \\
\text { significance }\end{array}$ & -- & 10.52 & -- & 13.94 & -- & 18.88 & -- & 16.49 \\
\hline Number of Obs & 305 & 305 & 300 & 300 & 302 & 302 & 293 & 293 \\
\hline \multicolumn{9}{|c|}{ African Women } \\
\hline & \multicolumn{2}{|c|}{$24-26$} & \multicolumn{2}{|c|}{$27-29$} & \multicolumn{2}{|c|}{$30-32$} & \multicolumn{2}{|c|}{$33-34$} \\
\hline & OLS & TSLS & OLS & TSLS & OLS & TSLS & OLS & TSLS \\
\hline $\begin{array}{l}\text { Pupil/Teacher Ratio } \\
\text { Black Schools } 1991\end{array}$ & $\begin{array}{l}-.0042 \\
(.0009)\end{array}$ & $\begin{array}{l}-.0074 \\
(.0016)\end{array}$ & $\begin{array}{l}-.0050 \\
(.0009)\end{array}$ & $\begin{array}{l}-.0101 \\
(.0016)\end{array}$ & $\begin{array}{l}-.0063 \\
(.0010)\end{array}$ & $\begin{array}{l}-.0103 \\
(.0016)\end{array}$ & $\begin{array}{l}-.0070 \\
(.0012)\end{array}$ & $\begin{array}{l}-.0109 \\
(.0020)\end{array}$ \\
\hline $\begin{array}{l}\text { Mean Years of Educ } \\
\text { Adults } 49-59\end{array}$ & $\begin{array}{l}-.0055 \\
(.0032)\end{array}$ & $\begin{array}{l}-.0080 \\
(.0034)\end{array}$ & $\begin{array}{l}-.0028 \\
(.0033)\end{array}$ & $\begin{array}{l}-.0067 \\
(.0036)\end{array}$ & $\begin{array}{l}-.0092 \\
(.0034)\end{array}$ & $\begin{array}{l}-.0124 \\
(.0036)\end{array}$ & $\begin{array}{l}-.0102 \\
(.0039)\end{array}$ & $\begin{array}{l}-.0133 \\
(.0042)\end{array}$ \\
\hline Number of Obs & 292 & 292 & 288 & 288 & 290 & 290 & 286 & 286 \\
\hline
\end{tabular}

Notes: Standard errors in parentheses. Weighted least squares, with inverse sampling variances from the first stage used as weights. Two-stage least squares estimates use the 1996 pupil-weighted median learner/educator ratio as an instrument for the average pupil/teacher ratio in Black schools in 1991.

The first stage regression when all magisterial districts with observations in both 1991 and 1996 are present is:

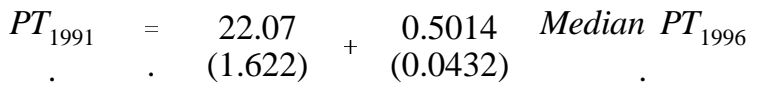

(Number of observations $=308$. Standard errors presented in parentheses.) 


\section{Figure I}

Wages and schooling Black men 24-34

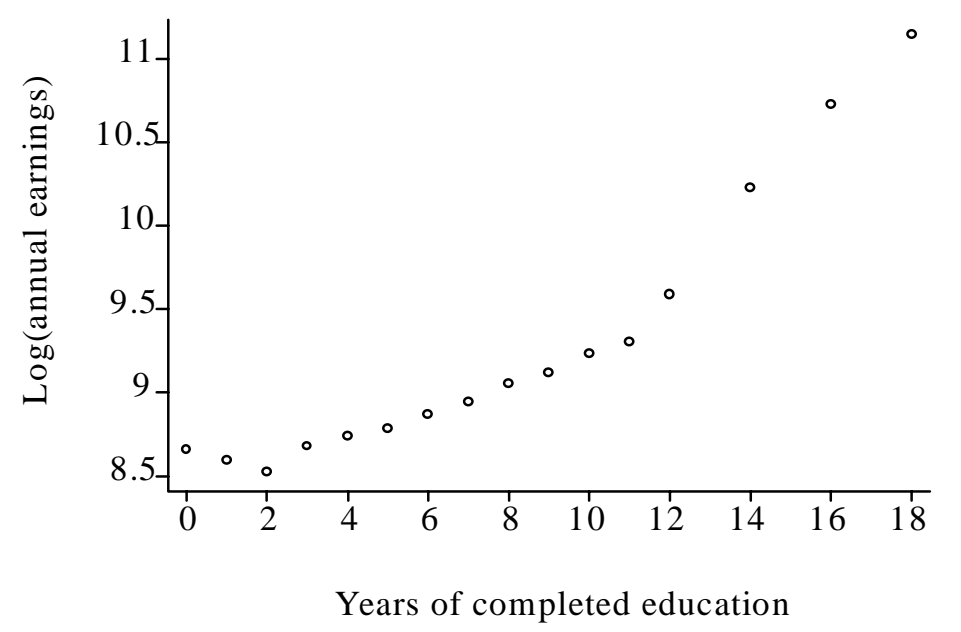

Wages and schooling Black women 24-34

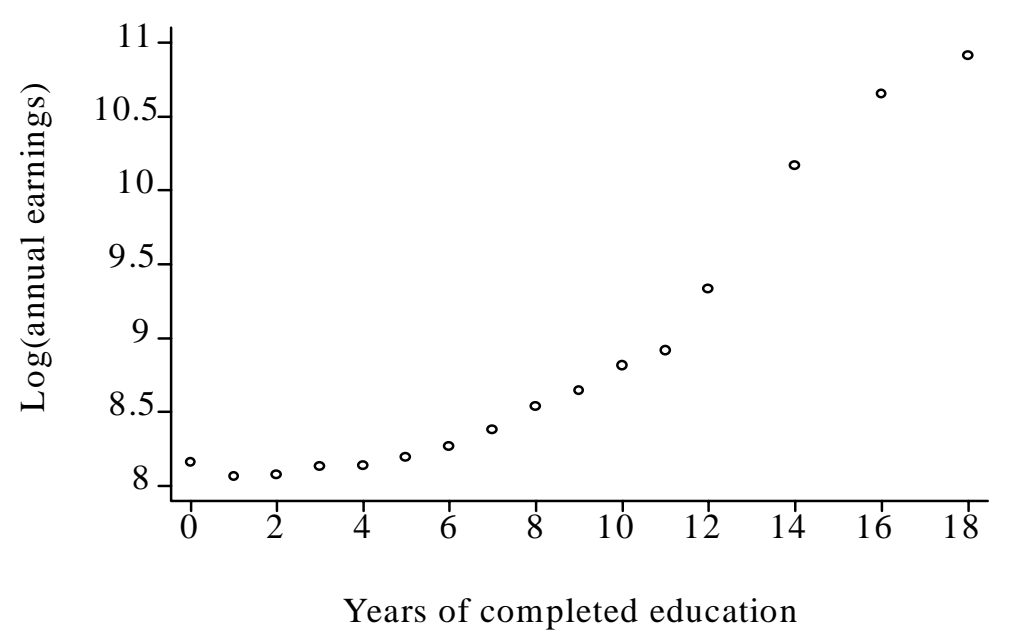




\section{Figure II}

Effect of pupil/teacher ratio on return to education

Estimated for each age separately, Black men

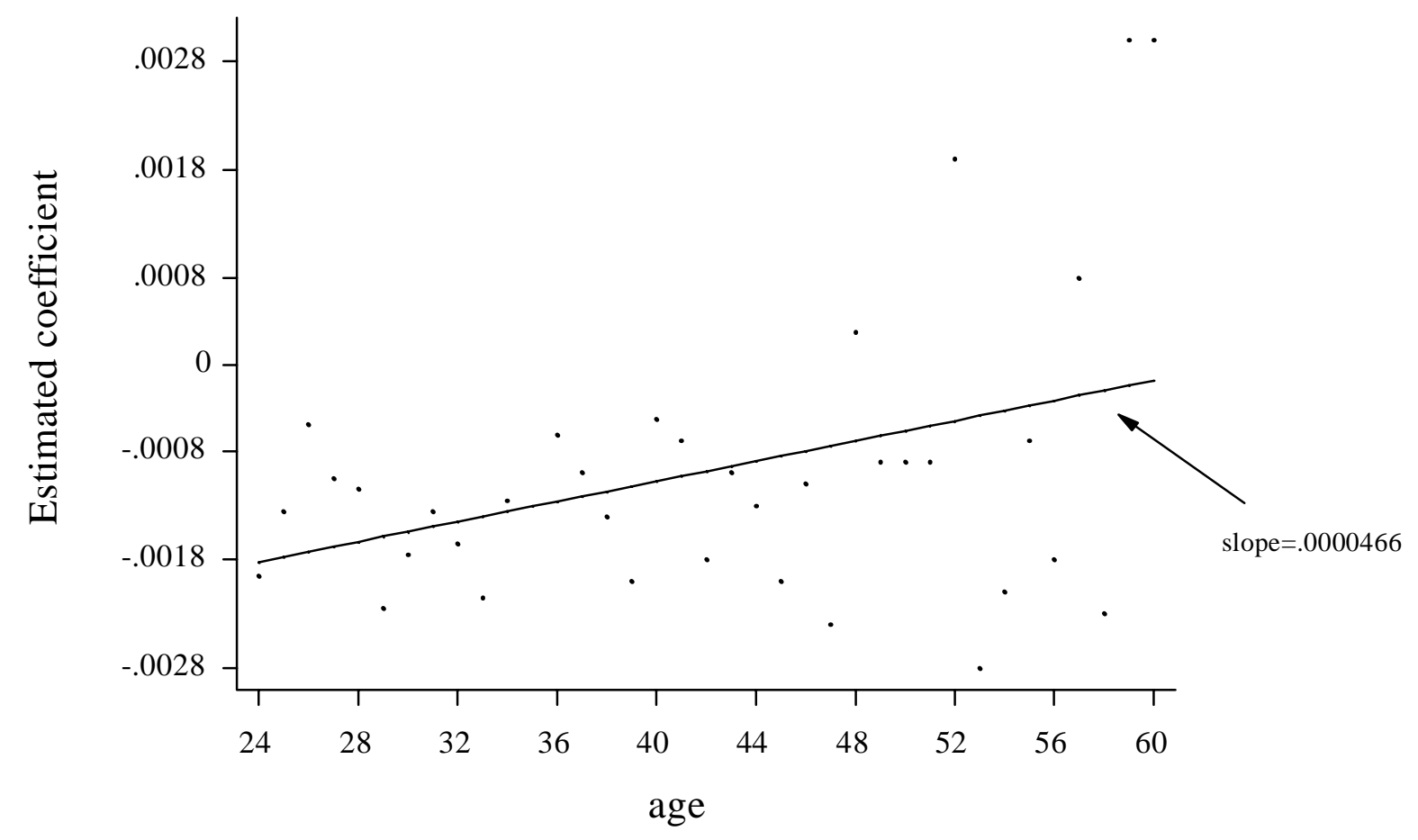




\section{Map I}

\section{Pupil/Teacher Ratio by Magisterial District Black Schools 1991}

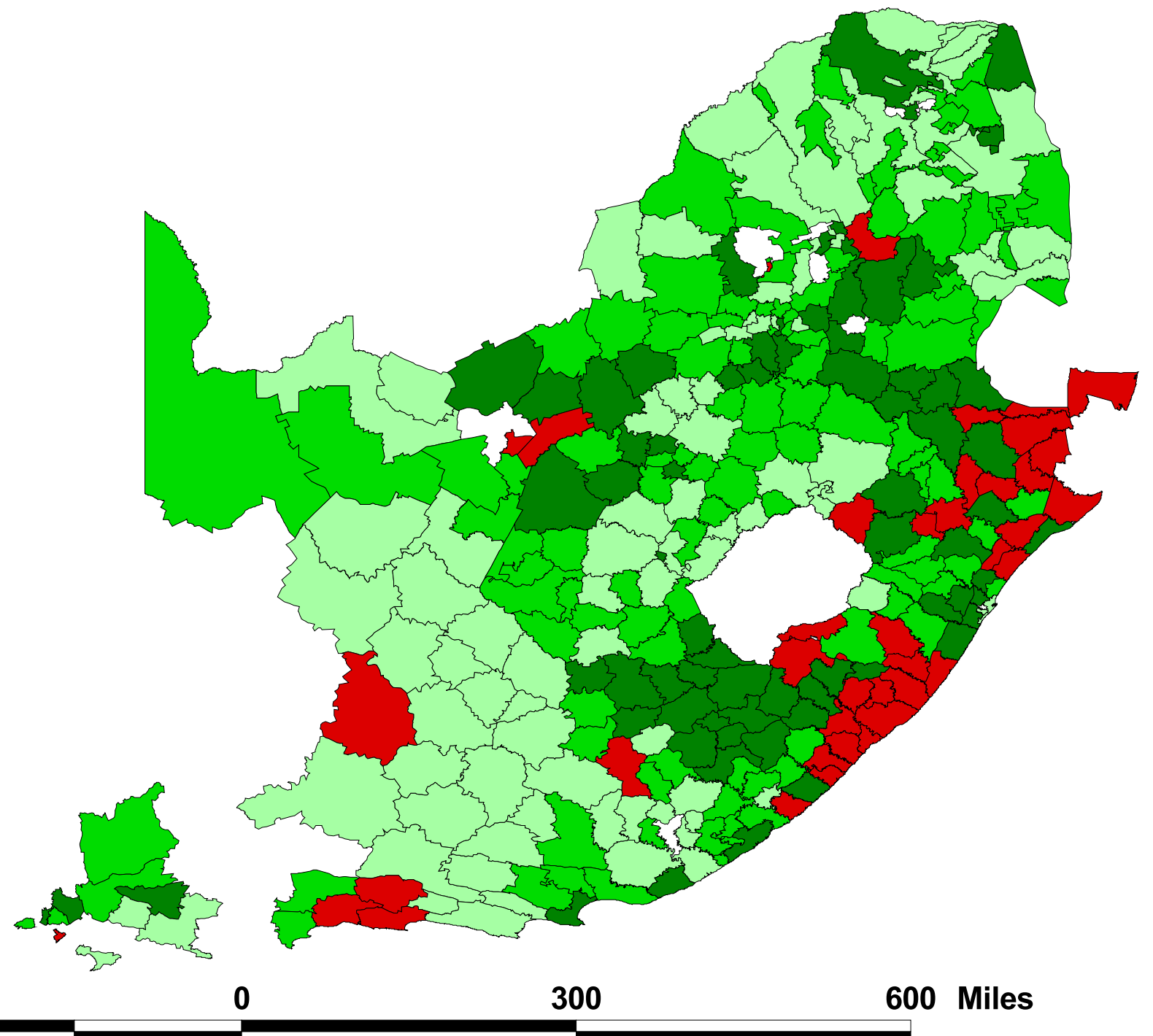

District.shp

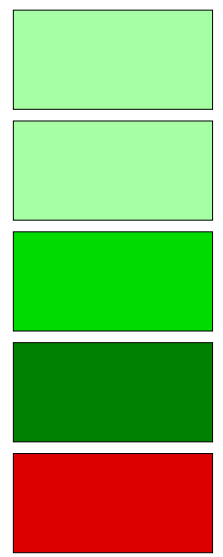

$12-30$

$30-37$

$37-42$

$42-48$

48 - 67 
To order any of these papers in hard copy, see instructions at the end of this list. To subscribe to all NBER Working Papers or the papers in a single area, see instructions inside the back cover.

Number $\quad \underline{\text { Author(s) }}$

7348

7349

7350

7351

7352

7353

7354

7355

7356

7357

7358

7359

7360

7361
Jonathan Gruber

Edward P. Lazear

Tamim Bayoumi

Taizo Motonishi

Hiroshi Yoshikawa

Daron Acemoglu

Robert Shimer

Jeff Grogger

Charles Michalopoulos

Roberto Rigobon

Ricardo J. Caballero

Mohamad L. Hammour

Alec Ian Gershberg

Michael Grossman

Fred Goldman

Robert E. Lipsey

Vernon Henderson

Iain Cockburn

Rebecca Henderson

Scott Stern

Douglas Holtz-Eakin

John W. Phillips

Harvey S. Rosen

Bong-Chan Kho

René M. Stulz $\underline{\text { Title }}$

Date

The Wealth of the Unemployed: Adequacy and Implications for Unemployment Insurance

Educational Production

9/99

The Morning After: Explaining the Slowdown in Japanese Growth in the 1990s

9/99

Causes of the Long Stagnation of Japan during the

9/99 1990's: Financial or Real?

Productivity Gains From Unemployment Insurance

9/99

Welfare Dynamics under Time Limits

9/99

On the Measurement of the International Propagation

$9 / 99$ of Shocks

The Cost of Recessions Revisited: A Reverse-

Liquidationist View

9/99

Competition and the Cost of Capital Revisited: Special

Authorities and Underwriters in the Market for Tax-

exempt Hospital Bonds

Foreign Production by U.S. Firms and Parent Firm

$9 / 99$

Employment

Marshall's Economies

9/99

The Diffusion of Science-Driven Drug Discovery:

Organizational Change in Pharmaceutical Research

$9 / 99$

Estate Taxes, Life Insurance, and Small Business

9/99

Banks, the IMF, and the Asian Crisis

9/99

\section{You can download these and other papers at the NBER Web site: WWw.nber.org}

Free searchable abstracts are also available at the site. 
To order any of these papers in hard copy, see instructions at the end of this list. To subscribe to all NBER Working Papers or the papers in a single area, see instructions inside the back cover.

\begin{tabular}{|c|c|c|c|}
\hline Number & $\underline{\text { Author(s) }}$ & $\underline{\text { Title }}$ & $\underline{\text { Date }}$ \\
\hline 7362 & $\begin{array}{l}\text { Jagadeesh Gokhale } \\
\text { Laurence J. Kotlikoff }\end{array}$ & $\begin{array}{l}\text { Social Security's Treatment of Postwar Americans: } \\
\text { How Bad Can It Get? }\end{array}$ & 9/99 \\
\hline 7363 & $\begin{array}{l}\text { Bruce D. Meyer } \\
\text { Dan T. Rosenbaum }\end{array}$ & $\begin{array}{l}\text { Welfare, the Earned Income Tax Credit, and the } \\
\text { Labor Supply of Single Mothers }\end{array}$ & 9/99 \\
\hline 7364 & $\begin{array}{l}\text { Dani Rodrik } \\
\text { Andrés Velasco }\end{array}$ & Short-Term Capital Flows & \\
\hline 7365 & $\begin{array}{l}\text { Michael D. Bordo } \\
\text { Lars Jonung }\end{array}$ & $\begin{array}{l}\text { The Future of EMU: What Does the History of } \\
\text { Monetary Unions Tell Us? }\end{array}$ & 9/99 \\
\hline 7366 & Emmanuel Saez & Do Taxpayers Bunch at Kink Points? & 9/99 \\
\hline 7367 & Emmanuel Saez & $\begin{array}{l}\text { The Effect of Marginal Tax Rates on Income: A Panel } \\
\text { Study of 'Bracket Creep' }\end{array}$ & $1 \quad 9 / 99$ \\
\hline 7368 & $\begin{array}{l}\text { Alan L. Gustman } \\
\text { Thomas L. Steinmeier }\end{array}$ & $\begin{array}{c}\text { What People Don't Know About Their Pensions } \\
\text { and Social Security: An Analysis Using Linked Data } \\
\text { From The Health and Retirement Study }\end{array}$ & \\
\hline 7369 & $\begin{array}{l}\text { Wolfgang Keller } \\
\text { Arik Levinson }\end{array}$ & $\begin{array}{l}\text { Environmental Compliance Costs and Foreign Direct } \\
\text { Investment Inflows to U.S. States }\end{array}$ & \\
\hline 7370 & $\begin{array}{l}\text { Michael Baker } \\
\text { Gary Solon }\end{array}$ & $\begin{array}{l}\text { Earnings Dynamics and Inequality among Canadian } \\
\text { Men, 1976-1992: Evidence from Longitudinal Income } \\
\text { Tax Records }\end{array}$ & $9 / 99$ \\
\hline 7371 & $\begin{array}{l}\text { Michael Baker } \\
\text { Nicole M. Fortin }\end{array}$ & $\begin{array}{l}\text { Occupational Gender Composition and Wages in Can } \\
\text { 1987-1988 }\end{array}$ & lada: $9 / 99$ \\
\hline 7372 & $\begin{array}{l}\text { B. Douglas Bernheim } \\
\text { Lorenzo Forni } \\
\text { Jagadeesh Gokhale } \\
\text { Laurence J. Kotlikoff }\end{array}$ & $\begin{array}{l}\text { The Adequacy of Life Insurance: Evidence from the } \\
\text { Health and Retirement Survey }\end{array}$ & $10 / 99$ \\
\hline 7373 & $\begin{array}{l}\text { Paul A. David } \\
\text { Bronwyn H. Hall } \\
\text { Andrew A. Toole }\end{array}$ & $\begin{array}{l}\text { Is Public R\&D a Complement or Substitute for Private } \\
\text { R\&D? A Review of the Econometric Evidence }\end{array}$ & $10 / 99$ \\
\hline 7374 & $\begin{array}{l}\text { Peter Cappelli } \\
\text { David Neumark }\end{array}$ & $\begin{array}{l}\text { Do "High Performance" Work Practices Improve } \\
\text { Established-Level Outcomes? }\end{array}$ & $10 / 99$ \\
\hline
\end{tabular}

\section{You can download these and other papers at the NBER Web site: wWw.nber.org}

Free searchable abstracts are also available at the site. 
To order any of these papers in hard copy, see instructions at the end of this list. To subscribe to all NBER Working Papers or the papers in a single area, see instructions inside the back cover.

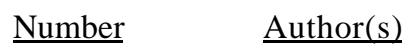

$7375 \quad$ Charles I. Jones

7376

7377

7378

7379

7380

7381

7382

7383

7384

7385

7386

7387

Jeremy C. Stein

George Chacko

Luis M. Viceira

Victor R. Fuchs

James P. Smith

Charles Engel

Cedric Tille

Michael Klein

Giovanni Olivei

Jean Abraham

Ashish Arora

Martin Gaynor

Alan M. Taylor

Alberto Alesina $\underline{\text { Title }}$

Date

Was an Industrial Revolution Inevitable?

$10 / 99$

Economic Growth Over the Very Long Run

Differences of Opinion, Rational Arbitrage and Market Crashes

Bruce A. Blonigen

Stephen E. Haynes

Michael D. Hurd

Olivia S. Mitchell

Michael B. Devereux

Stephen L. Mehay

Rosalie Liccardo Pacula

Douglas Wholey

Gerardo della Paolera

Stephan Danninger

Massimo V. Rostagno
Dynamic Consumption and Portfolio Choice with

Stochastic Volatility in Incomplete Markets

Antidumping Investigators and the Pass-Through of

Exchange rates and Antidumping Duties

The Future of Health Economics

$10 / 99$

Anticipated and Actual Bequests

$10 / 99$

New Trends in Pension Benefit and

Retirement Provisions

Exchange Rate Pass-through and the Welfare

$10 / 99$

Effects of the Euro

The Effectiveness of Workplace Drug Prevention

$10 / 99$

Policies: Does 'Zero Tolerance' Work?

Capital Account Liberalization, Financial Depth and

Economic Growth

Enter at your own risk: HMO participation and

enrollment in the Medicare risk market

$10 / 99$

Internal Versus External Convertibility and Developing- 10/99

Country Financial Crises: Lessons from the Argentine

Bank Bailout of the 1930's

Redistribution Through Public Employment: The Case $10 / 99$ of Italy

\section{You can download these and other papers at the NBER Web site: wWw.nber.org}

Free searchable abstracts are also available at the site. 
To order any of these papers in hard copy, see instructions at the end of this list. To subscribe to all NBER Working Papers or the papers in a single area, see instructions inside the back cover.

\begin{tabular}{|c|c|c|c|}
\hline Number & $\underline{\text { Author(s) }}$ & $\underline{\text { Title }}$ & Date \\
\hline 7388 & $\begin{array}{l}\text { Oliver Hart } \\
\text { John Moore }\end{array}$ & $\begin{array}{l}\text { On the Design of Hierarchies: Coordination Versus } \\
\text { Specialization }\end{array}$ & $10 / 99$ \\
\hline 7389 & $\begin{array}{l}\text { Joshua Aizenman } \\
\text { Nancy Marion }\end{array}$ & $\begin{array}{l}\text { Uncertainty and the Disappearance of International } \\
\text { Credit }\end{array}$ & 10 \\
\hline 7390 & $\begin{array}{l}\text { David M. Cutler } \\
\text { Ellen Meara }\end{array}$ & The Technology of Birth: Is it Worth It? & $10 / 99$ \\
\hline 7391 & Joel Waldfogel & $\begin{array}{l}\text { Preference Externalities: An Empirical Study of Who } \\
\text { Benefits Whom in Differentiated Product Markets }\end{array}$ & $10 / 99$ \\
\hline 7392 & $\begin{array}{l}\text { James M. Poterba } \\
\text { Andrew A. Samwick }\end{array}$ & $\begin{array}{l}\text { Taxation and Household Portfolio Composition: U.S. } \\
\text { Evidence from the 1980's and 1990's }\end{array}$ & $10 / 99$ \\
\hline 7393 & Bennett T. McCallum & Theoretical Issues Pertaining to Monetary Unions & $10 /$ \\
\hline 7394 & Alan M. Taylor & $\begin{array}{l}\text { Latin America and Foreign Capital in the Twentieth } \\
\text { Century: Economics, Politics, and Institutional Change }\end{array}$ & $10 / 9$ \\
\hline 7395 & Bennett T. McCallum & $\begin{array}{l}\text { Analysis of the Monetary Transmission Mechanism: } \\
\text { Methodological Issus }\end{array}$ & \\
\hline
\end{tabular}

Owen A. Lamont

The Diversification Discount: Cash Flows vs. Returns $\quad 10 / 99$

Christopher Polk

$7397 \quad$ V. Joseph Hotz

Susan Williams McElroy

Seth G. Sanders

Teenage Childbearing and its Life Cycle Consequences: 10/99 Exploiting a Natural Experiment

Anne Case

Motohiro Yogo

Does School Quality Matter? Returns to Education and 10/99 the Characteristics of Schools in South Africa

Copies of the above working papers can be obtained for $\$ 10.00$ per copy (plus $\$ 10.00$ per order for shipping for all locations outside the continental U.S.) to Working Papers, NBER, 1050 Massachusetts Avenue, Cambridge, MA 021385398. Pre-payment is required on all orders and may be made by check or credit card. Checks should be made payable to the NBER and must be in dollars drawn on a U.S. bank. If paying by credit card, include the cardholder's name, account number, and expiration date. For all orders, please be sure to include your return address and telephone number. Working papers may also be ordered by telephone (868-3900), fax (617-868-2742), or email (orders@ nber.org).

\section{You can download these and other papers at the NBER Web site: WWw.nber.org}

Free searchable abstracts are also available at the site. 


\section{Map III}

Returns to education by district of origin

Black men aged 24-34

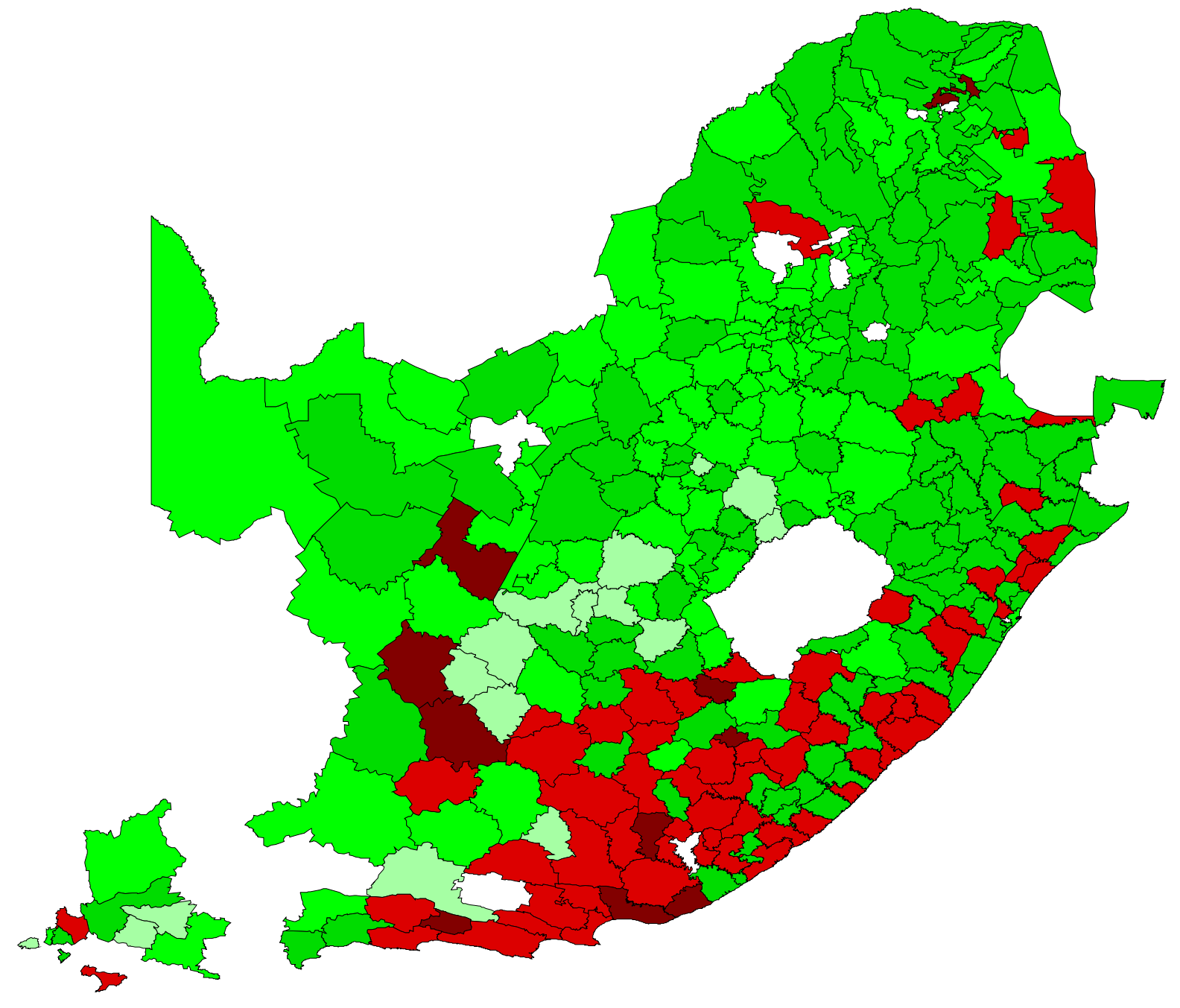

District.shp

$-0.132--0.029$ $-0.029-0.047$ $0.047-0.088$ $0.088-0.136$ $0.136-0.218$ 